\title{
CELİK TAHIL DEPOLAMA SİLOLARININ SİSMİK ANALİZİ ÜZERİNE GENEL BİR DEĞERLENDİRME VE YENİ ANALIZZ YAKLAŞIMLARI
}

\author{
Ali İhsan ÇELİK${ }^{1 *}$, Mehmet Metin KÖSE² \\ ${ }^{1}$ Kayseri Üniversitesi, Tomarza Mustafa Akıncıoğlu Meslek Yüksekokulu, İnşaat bölümü, Kayseri, Türkiye \\ ${ }^{2}$ K. Maraş Sütçü İmam Üniversitesi, Mühendislik Fakültesi, İnşaat Mühendisliği Bölümü, K.Maraş, Türkiye
}

\begin{tabular}{|c|c|}
\hline Anahtar Kelimeler & Öz \\
\hline $\begin{array}{l}\text { Silo, } \\
\text { Sismik Analiz, } \\
\text { Ayrık Elemanlar Metodu, } \\
\text { Sonlu Elemanlar Metodu. }\end{array}$ & $\begin{array}{l}\text { Tahıl depolama silolarının önemi tarımsal endüstrinin ihtiyacını karşılamak için her } \\
\text { geçen gün artmaktadır. Bu silolarda; buğday, arpa, yulaf, mısır, pirinç ve benzeri } \\
\text { temel gıda maddeleri depolanmaktadır. Sismik bölgelerde inşa edilen tahıl } \\
\text { depolama siloları, inşaat mühendisliğinin ilgisini çekmektedir. Sismik kaynaklı } \\
\text { basınçlar altında özellikle ince cidarlı siloların, cidarlarında kritik burkulmalar ve } \\
\text { patlamalar meydana gelebilmektedir. Bu çalışma öncelikle silolar hakkında önemli } \\
\text { sismik analizlerin genel değerlendirmesini içermekle birlikte, yeni tasarım } \\
\text { yaklaşımlarını da sunmaktadır. Tahıl depolama silolarının sismik analizlerinin } \\
\text { doğru yapılması, meydana gelebilecek hasarların önlenmesine doğrudan katkı } \\
\text { sağlayacaktır. Silo içindeki tahıllar; statik basınçlarının yanı sıra, sismik hareket } \\
\text { sırasında taneciklerin kendi aralarında ve silo cidarında oluşturdukları } \\
\text { sürtünmelerden dolayı farklı dinamik basınçlara sebep olmaktadırlar. Silo ve içeriği } \\
\text { zemin ivmesine maruz kaldığında, partiküllerde ve silo duvarında sert davranışlar } \\
\text { meydana gelmektedir. Sonlu elemanlar metodu ile yapılan analizlerde taneciklerin } \\
\text { yatay ve dikey ivmelenmeye bağlı hareketlerinin simüle edilerek silo cidarında } \\
\text { oluşacak gerilmelerin ve burkulmaların gözlemlenmesi gerekir. Literatürdeki sonlu } \\
\text { elemanlar analizlerinde, silo içindeki tanecikler arası boşluklar ve sıkıştırma } \\
\text { oranlarının simülasyonunda eksiklikler vardır. Silo içindeki tahıl taneciklerinin } \\
\text { gerçeğe uygun bir şeklide, yani parçacıklı dökme malzeme (bulk material) olarak } \\
\text { simüle edilmesi gerekir. Simülasyonların ve analizlerin gerçeğe uygunluğunu } \\
\text { sağlamak için ayrı elemanlar metodu ile sonlu elemanlar metodunun birlikte } \\
\text { kullanılması yeni bir yaklașım olarak önerilmektedir. }\end{array}$ \\
\hline
\end{tabular}

\section{A GENERAL EVALUATION AND NEW ANALYSIS APPROACHES ON SEISMIC ANALYSIS OF STEEL GRAIN STORAGE SILOS}

\begin{tabular}{l}
\hline Keywords \\
\hline Silo, \\
Seismic Analysis, \\
Discrete Element Method, \\
Finite Element Method.
\end{tabular}

\begin{abstract}
The importance of grain storage silos is increasing day by day to satisfy the needs of the agricultural industry. In these silos; wheat, barley, oats, corn, rice, and similar basic foodstuffs are stored. Grain storage silos built in seismic regions attract the attention of civil engineering. Critical buckling and explosions may occur in the walls of thin-walled silos, especially under seismic source pressures. This study primarily includes an overview of important seismic analyzes about silos, but also presents new design approaches. Correct seismic analysis of grain storage silos will directly contribute to the prevention of possible damages. Cereals in the silo; Besides their static pressures, they cause different dynamic pressures due to the friction created by the particles among themselves and in the silo wall during seismic motion. When the silo and its contents are exposed to ground acceleration, harsh behavior occurs in the particles and the silo wall. In the analysis made with the finite element method, the movements of the particles due to horizontal and vertical acceleration should be simulated and the stresses and buckling in the silo wall should be observed. There are deficiencies in the finite element analysis in the literature, the intergranular gaps in the silo and the simulation of compression ratios. Grain particles in the silo must be simulated in a realistic way, ie as bulk material. It is
\end{abstract}

\footnotetext{
* ilgili yazar / Corresponding author: acelik@kayseri.edu.tr, +90-5332217635
} 
proposed as a new approach to use the discrete elements method and the finite elements method to ensure that the simulations and analyzes are rational.

Alıntı / Cite

Çelik, A. İ, Köse, M.M., (2020). Çelik Tahıl Depolama Silolarının Sismik Analizi Üzerine Genel Bir Değerlendirme ve Yeni Analiz Yaklașımları, Mühendislik Bilimleri ve Tasarım Dergisi, 8(2), 501-520.

\begin{tabular}{l|l|l}
\hline Yazar Kimliği / Author ID (ORCID Number) & \multicolumn{3}{|l}{ Makale Süreci / Article Process } \\
\hline A.İ. Çelik, 0000-0001-7233-7647 & Başvuru Tarihi / Submission Date & 05.02 .2020 \\
M.M. Köse, 0000-0002-7462-1577 & Revizyon Tarihi / Revision Date & 15.04 .2020 \\
& Kabul Tarihi / Accepted Date & 19.04 .2020 \\
& Yayım Tarihi / Published Date & 25.06 .2020 \\
\hline
\end{tabular}

\section{Giriş (Introduction)}

Çelik depolama siloları, betonarme depolardan farklı olarak hafif olmaları, kolay kurulmaları, sökülmeleri, taşınmaları, tadilatları v.b özellikleri nedeniyle, büyük miktarlardaki dökme malzemelerin (bulk materials) kısa ve uzun süreli depolanması için daha elverișlidirler. Tahıl depolama için elverișli olmaları kullanımlarını her geçen gün artırmaktadır. Son yıllarda madencilik, kimyasal, tarım ve gıda işleme dâhil olmak üzere birçok sektörde artan bir şekilde kullanılmaktadırlar. Dökme malzeme (bulk material) içeren çelik yapılar genel olarak silo, ambar, depo ve tank olarak isimlendirilmektedirler. Bu çalışmada, silo ifadesi genel tahıl deposu anlamında kullanılacaktır. Dünyanın en etkili deprem kuşaklarından biride ülkemizde bulunmaktadır. Geçmiște meydana gelen birçok yıkıcı deprem büyük hasarlara sebep oldu. Önlem alınmadı̆̆ı takdirde gelecekte de ciddi hasarlara sebep olacaktır (Demir \& Saltan, 2017). Yıkıcı depremler esnasında tahıl depolama silolarında da çeşitli hasarlar ve burkulmalar meydana gelmektedir. Bu ince cidarlı çelik yapıların, sismik tasarım problemlerindeki karmaşıklığı azaltmak için mevcut bilginin pratik kullanımına ve daha ileri araştırma ihtiyaçlarının kapsamlı bir şekilde anlaşılmasına ihtiyaç vardır. Siloların sismik tasarımı ve analizi, çeşitli standartlar ve önerilen uygulamalar tarafından yönetilmektedir. Amerika Birleşik Devletleri'nde, ANSI / ASAE EP433 mühendislik uygulaması, serbest akan tahılları depolamak için kullanılan merkezi olarak yüklenmiş ve boşaltılan silolardaki tane basınçlarını tahmin etme yöntemlerini sunmaktadır. Avrupa'da, EN 1991-4 Eurocode 1: Actions on structures-Part 4: Silos and Tanks; Avrupa birliği ülkeleri tarafından kullanılması zorunlu bir standarttır. AS 3774-1996, Australian Standard Loads on bulk solids containers kullanıcılara, taneler, silolar, depolar ve döküm hunileri de dahil olmak üzere, granül dökme malzemelerin depolanması için, depolama silolarının tasarımı ve yüklerin belirlenmesi için ulusal olarak kabul edilebilir kurallar sunmaktadır(ANSI/ASAE EP433 DEC (R2011)Loads Exerted by Free-Flowing Grain on Bins; A. Standard, 1996; B. Standard, 2006)., Bu standartlar arasında farklılıklar bulunmaktadır. Ayrıca, pek çok ortak silo tasarım koşulu, bunların hiçbiri tarafından tam olarak karşılanamamaktadır (Carson \& Craig, 2015). Sismik tasarım hükümleri dışında, analitik formülasyon, deneysel yaklaşım ve sonlu elemanlar yöntemi gibi farklı sismik analiz yöntemleri de bulunmaktadır.

Deprem esnasında, siloların çeperleri tipik olarak silo içindeki partikül materyali tarafından üretilen hem normal hem de kayma gerilmelerine (normal basınçlar, dikey ve yatay sürtünme kuvvetleri) maruz kalırlar. Normal basınç ve kayma sürtünme kuvvetlerinin büyüklüğü ve dağılımı çeperin yüksekliği, içindeki malzemenin özelliklerine ve silonun doldurulup doldurulmadığına bağlıdır. Yanal yüklerin etkisi özellikle daha ağır malzemeler içeren ve daha büyük silolar üzerinde önemli olabilmektedir, çünkü yatay sismik yükün büyüklüğü silo ağırlığıla doğrudan orantılıdır (Dogangun, Karaca, Durmus, \& Sezen, 2009). Deprem sırasında, tanecikli dökme malzeme silo içinde salınabileceğinden, malzeme akışından kaynaklanan yanal yükler ile yanal sismik yükler aynı anda dikkate alınmalıdır.

Roberts tarafından, (1882) yılında yapılan bir çalışmada, dökme malzemeleri içeren siloların statik durumdaki yatay ve düşey basınçları belirlenmiştir (Rotter \& Hull, 1989). Roberts (1884), depolanan malzemelerin ağırlığının sürtünmeyle duvarlara aktarıldığını ve duvarlardaki yatay ve dikey basınçların eşit olmadığını ortaya çıkarmıştır (Li, 1994). Daha sonra siloların statik tasarımı, Pozzati ve Ceccoli (1972), Janssen (1895) ve Koenen (1896) tarafından, silo duvarları ile etkileşime giren tane kütlesinin bir kısmının tanımlanmasına yol açan fiziksel idealleşmeye uygun olarak yapılması önerilmiştir. Statik koşullarda, daha ayrıntılı olarak, Janssen ve Koenen yukarıda belirtilen etkileșimli kütleyi, koruma durumunda, tahıl kütlesinin bir kısmının tamamen sürdürülmesini sağlayan, tahılın duvara temas yüzeyi boyunca sürtünmeli dikey gerilmelerin tam olarak duvarlar tarafından sömürülmesi ile temsil edilen çalışmayı yapmışlardır (Janssen, 1895; Koenen, 1896; Pozzati \& Ceccoli, 1972). Bu idealizasyon, sürtünmeli dikey gerilmelerin tam olarak kullanılması nedeniyle, silo duvarlarında tahıl benzeri malzemenin sebep olduğu eylemler için bir üst sınıra karşılık geldiğinden daha emniyetlidir. Eurocode 1 Part 4 hükümleri (EN 1991-4 2004) bu yaklaşıma dayanmaktadır.

Son yıllarda siloların sismik performanslarını belirlemek için birçok araştırma yapılmaktadır. Bu araştırmalarda siloların sismik davranışlarının tam olarak anlaşılmadığı vurgulanmaktadır. Siloların sismik analizi çok karmaşık 
olduğundan, kullanılan dökme malzemelerin özellikleri ve dökme malzemelerin silo çeperi ile nasıl etkileşime girdiği gibi çeşitli parametrelerin ayrıntılı olarak değerlendirilmesinin gerekliliği ortaya çıkmıştır. İki eleman arasındaki temas, yük aktarma tekniği açısından iki ya da daha fazla temas yüzeyi arasındaki ilişkinin yapısına bağlıdır. Temas durumunun doğrudan incelenmesi ve kesin bir şekilde değerlerin ölçülmesi oldukça zordur. Temas problemi temas gerilmelerini olușturan elemanların davranışının, malzeme özelliklerine bağlı olmasından dolayı karmaşıktır (Yaylacı \& Terzi, 2018). Silvestri ve arkadaşlarının (2012) yaptıkları çalışmalar bu alana önemli katkılar sağlamıştır. Çalışmalarında, tahılların deprem sırasındaki etkin davranışlarının değerlendirilmesinde analitik çözümler sunmuşlardır. Etkili kütlenin (yani, silo duvarına dinamik uyarım altında yatay olarak iten kütle), özellikle geniş ve kısa (squat) bir geometri ile karakterize edilen silolar için Eurocode 8 tarafından verilenden çok daha düșük olduğunu ifade etmişlerdir (Silvestri, Gasparini, Trombetti, \& Foti, 2012). Pieraccini ve vd., (2015) Silvestri'nin teorisini geliștirmiş ve revize ederek yeni sonuçlar ortaya çıkarmışlardır (Pieraccini, Silvestri, \& Trombetti, 2015). Silvestri ve vd., (2016), önerilen analitik formülasyonları doğrulamak için bir dizi sarsma masası testi gerçekleştirmişlerdir (Silvestri ve vd., 2016). Livaoğlu ve Durmuş (2015), düztabanlı yerden destekli silolardaki dinamik malzeme basınçlarını ve boyutlarını tahmin etmek için basitleştirilmiş bir sismik analiz prosedürü kullanmışlar. Hem geniş hem de Narin bir silo kullanarak yapmış oldukları çalışmadan elde edilen sonuçlar, EN1998-4 ile elde edilen bulgularla karşılaştırmışlardır. Önerilen analitik modelin, özellikle dinamik malzeme basıncının analizi açısından iyi bir sonuç sağladığı fikrine varılmıştır. Eurocode'da önerilen analitik yöntemi kullanarak, geniş siloları için dinamik malzeme basıncının hafife alınabileceğini, ancak Narin silolar için dinamik malzeme basıncının daha etkili olduğunu belirtmișler (Livaoglu \& Durmuş, 2016). Butenweg ve vd., iki farklı silo analiz yöntemini karşılaştırmışlardır. İlk yol, sismik yükleme ile duvara etki eden statik eşdeğer yüklerin modellenmesidir, diğeri ise, duvar ve granül dökme malzeme arasındaki etkileşimin neden olduğu doğrusal olmayan olayların dikkate alındığı bir zaman geçmişi (time history) analizidir. Karşılaştırma sonucunda, statik eşdeğer yükler için doğrusal olmayan bir simülasyon modeliyle ve geniş silonun, statik eșdeğer yüklere sahip yaklaşımında, alt güvenlik sınırından daha yüksek sonuçlarla varılmıştır. Bunun nedeni, yük yaklaşımında geniş bir silo söz konusu olduğunda, gerilmenin büyük bir kısmının, dökme malzemenin sürtünmesiyle doğrudan giderildiği gerçeğini yeterli hassasiyette modellenememesindendir (Butenweg, Rosin, \& Holler, 2017). Narin ve geniş olarak ifade edilen silolara ait temsili görseller Şekil 1. de sunulmuştur.
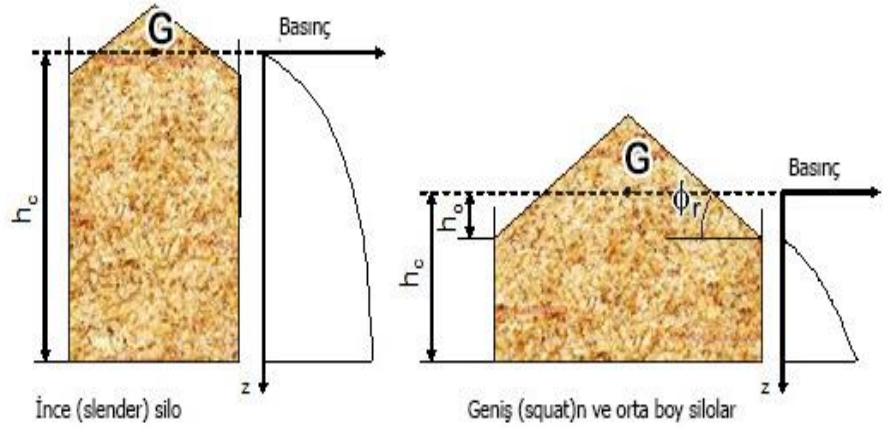

Şekil 1. Narin ve Geniş silolar (Slender and Squat silos)

Mehretehran ve Maleki (2018), tabanda yatay uyarmalara maruz kalan çelik siloların dinamik burkulma davranışını incelemek için farklı boy oranlarına sahip üç siloyu kullanarak Elastik-plastik burkulma direncini, Artımlı Dinamik Analizler (IDA) kullanarak tahmin yürütmüşlerdir. Buna göre, burkulma anında kritik taban kesme, taban momenti ve tepe yer ivmesi (PGA) hesaplanmıştır. Üstelik silo duvarlarındaki dökme katı maddelerden (bulk material) kaynaklanan ilave normal basınçlar, Eurocode 8 ile değerlendirilmiş ve karşılaştırılmıştır. Elde edilen sonuçlar, Narin siloların, burkulma başarısızlığına karşı daha savunmasız olduklarını, buna karşılık geniş siloların, aynı sismik koşullar altında önemli ölçüde daha yüksek bir direnci temsil ettiğini göstermiştir (Mehretehran \& Maleki, 2018). Siloların güvenliği kadar ekonomikliği de önemlidir. İnce cidarlı silolar daha ekonomik olduğundan firmaların tercih ettiği bir tasarım modelidir, dolayısıyla deprem yer hareketine karşı bu siloların performanslarının artırılması gerekir. Braun ve Eibl (1998)'e göre, deprem yüklemesine maruz kalan siloda simetrik olmayan basınç dağılımları meydana gelir ve cidarlarda ovalleşmeler oluşur (Braun \& Eibl, 2009). Rotter (2001), simetrik olmayan basınçlar sadece lokal burkulmala sebep olmakla kalmaz, aynı zamanda tüm siloyu membran gerilmeleri ile de etkilediğini ifade etmiştir (Rotter, 2001). Kanyilmaz ve Castiglioni (2017)'nın güncel çalışmasında, son yıllarda siloların birçoğunun depremler nedeniyle zarar gördüğünü ortaya çıkarılmışlardır. Gerçekten de, yüksek sismisite riskine sahip bölgelerde inşa edilen sanayii tesislerinin çoğunda bulunan siloların, sismik tasarım kodlarının son güncellemelerinden önce tasarlanmıș ve üretilmiş olmalarından dolayı, bu yapıların mevcut sismik güvenilirlikleri tartışmalıdır. Standart dışı yapıların çökmesinin neden olabileceği ekonomik, yaşamsal ve çevresel sorunlardan kaçınmak için, spesifik iyileștirme çözümleri geliştirilmeli ve acilen uygulanmalıdır. Onlar, çalışmalarında sismik izolasyon çözümünün uygulanabilirliğini göstermişlerdir. Hatta, mevcut bir sanayi kuruluşunda sismik savunmasızlığa sahip çelik silo 
sistemini araştırmışlar ve kavisli yüzeyi tek kaymalı sarkaç cihazlarından yararlanılarak bir iyileştirme çözümü önermişlerdir. Özgün dinamik analiz yöntemi, orijinal ve güçlendirme çözümlerin performanslarını karşılaştırmak için kullanılmıştır. Sismik izolasyon çözeltisinin yapısal yararları, elastik olmayan deformasyonlar, taban kesme, katlı ötelemeler ve izolatör deplasmanları açısından ölçülmüştür. Orijinal yapının sismik davranışı ve güçlendirilmiş yapısı kırılganlık eğrileriyle karşılaştırılmıștır (Kanyilmaz \& Castiglioni, 2017).

Silindirik çelik depolama tankları endüstrileşmenin başlangıcından beri sıvı türü maddeleri depolamak amacıyla yaygın olarak kullanılmaktadırlar. Dolayısıyla şimdiye kadar meydana gelen depremlerde, sıvı içeren çelik depoların hasarları araştırmacılar tarafından çokça gözlemlenmiş ve çeşitli sismik analizler yapılmıştır (Çelik, Köse, Akgül, \& Apay, 2019). Diğer yandan, siloların tarımsal ürün depolamada kullanılması daha yakın zamanlara dayanmaktadır ve hızla yaygınlaşmaktadır. Özellikle deprem tehlikesi yüksek olan bölgelerde bulunan siloların büyük çoğunluğu, tahıl ve tahıl ürünlerini depolamak için kullanıldığından, güvenliklerinin sağlanması büyük önem arz etmektedir. Her ne kadar bu siloların tasarım ve imalat standartları varsa da bu tasarım kodları daha çok tahılların doldurulması, tahliyesi üzerine yoğunlaşmaktadır. Diğer taraftan, tahıl depolama silolarının yapısal davranışını anlamak için şimdiye kadar yapılan araştırmalara göre, her yıl, kötü tasarım ve kötü inşaat nedeniyle diğer yapılardan daha fazla sayıda silo çökmektedir. Mesela, Taichung Limanı'ndaki siloların tamamı, merkez üssünden 70 km uzaklıktaki 1999 Chi-Chi, Tayvan depremi sırasında çökmüştür (Şekil 2.).

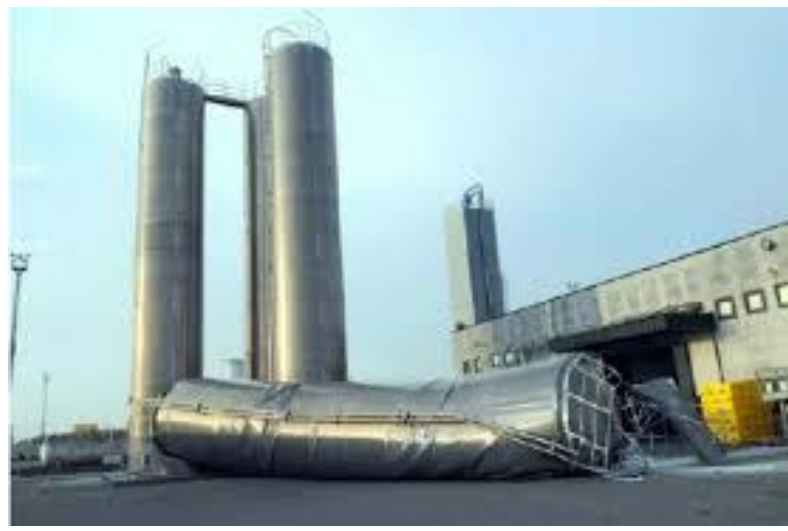

Şekil 2. Çelik silolarının çökmesi (Collapse of Silos)

En son 2011 de meydana gelen Van depreminde tarımsal endüstri alanında özellikle yükseltilmişs siloların çoğu kötü tasarım nedeniyle çökmüştür. Bu tür tesislerin tasarımı ve yapımı için kullanılan sismik uygulama tasarımlarında büyük revizyonlara ihtiyaç duyulduğu açıkça görülmektedir. Araştırmalar, tasarım prosedürlerinin yetersiz olduğunu ve bu nedenle silo yapılarının yapısal davranışı bilgisinde önemli gelişmelerin hala gerekli olduğunu göstermektedir.

Siloların sismik tasarımı için en geçerli Eurocode 8 hükümleri (2006) Younan ve Veletsos (1998) tarafından önerilen ve analitik formülasyon metoduna ve sadece kaba sert arayüzlü silo duvarını göz önüne alarak çalışma yürüten Rotter ve Hull (1989) çalışmasına dayanmaktadır. Silvestri tarafından yakın zamanda önerilen formülasyon tekniği de yetersiz kalmıștır. Daha sonra Silvestri teorisi olarak bilinen, Janssen ve Koenen tarafindan statik durum olarak tanımlanan ve eksenel simetri eksikliğinden kaynaklanan sorunların üstesinden gelmek için Pieraccin ve vd. (2015) tarafından modifiye edilerek yeni bir fiziksel model geliștirilmiştir. Bu modelden sonra, Pieraccin ve Silvestri, tahıl depolama silolarıyla ilgili tasarım hükümlerinin yetersiz olduğunu ve hala detaylı saha araştırmalarına ihtiyaç duyulduğunu ifade etmişlerdir.

Bu çalışma kapsamında, şimdiye kadar yapılmış önemli saha araştırmaları kronolojik bir bakışla özetlenmiştir. Son zamanlarda yapılan çalışmalara göre siloların sismik tasarımında hala önemli eksiklikler olduğu vurgulanmaktadır. Silo tasarımında en çok başvurulan Eurocode-8, Silvestri ve vd., çalışmasına dayandığı için orada da yetersizlikler söz konusudur. Buradan yola çıkarak, gelecekte bu alandaki eksikliklerin giderilmesi için öncelikle, deneysel çalışmaların 6 eksenli sismik sarsma tablası ile yapılması tavsiye edilmektedir. İkinci olarak, yapısal mekanik analizlerde sıklıkla bașvurulan sonlu elemanlar metodunun, ayrık elemanlar metodu ile birlikte kullanılması önerilmektedir. Tanecikli dökme malzeme içeren siloların sismik tasarımında, yeni modelleme teknikleri saha araștırmalarına önemli katkılar sağlayacaktır. Literatürde de sıklıkla bahsedilen silo içindeki tanecikli dinamik kütlenin modellenmesi, yeni teknoloji yazılımlarla daha gerçekçi simülasyonlar ve analizler yapılabilir. EDEM yazılım DEM (discreet element method) yani ayrık elemanlar metodunu kullanarak tanecikli dökme malzemeleri dinamik şartlara uygun olarak modelleyebilmektedir. Buradan, silo içindeki tahılların EDEM yazılımı ile modellenmesi ve ANSYS Workbench' teki silo içine EDEM for ANSYS aracı ile analiz verilerinin çekilerek sonlu elemanlar metodu ile sonuçları gözlemlemek daha gerçekçi olacaktır. Çünkü sismik hareket esnasında, tana- 
tane, tane-duvar etkileşimi ve aynı zamanda tanecikler arasındaki boşlukların silo burkulmasında en etkili parametrelerdendir. Bu parametrelerin mekanik özelliklerinin doğru belirlenmesi ve doğru modellenmesi ayrık elemanlar metodu ile mümkündür. Bu modelleme sonlu elemanlar metodu ile birlikte kullanılması, analizlerin çok yönlü ele alınmasını sağlayacaktır. Buradan yola çıkarak bu çalışma sonucunda, ayrık elemanlar metodu ile sonlu elemanlar metodunun birlikte kullanılması ile ilgili örnek bir çalıșma yapılmıştır. Önerilen bu yeni yaklaşımlar, yeni projelerle desteklenmesi, önemini ortaya çıkaracak ve daha hızlı sonuçların elde edilmesini sağlayacaktır.

\section{Siloların Sismik Davranışı (Seismic Behavior of Silos)}

Deprem hareketi, yapı üzerinde herhangi bir yatay yönü etkileyebilecek şekilde yanal kuvvetlere neden olur. Deprem bölgelerinde inşa edilen tüm yapılar bu yanal kuvvetlere dayanacak șekilde tasarlanması gerekir. Deprem kuvvetlerinin değerlendirilmesi zordur ve ilgili bölgelerde uzun süreli gözlem gerektirir. Deprem sırasında yapı, temellerinin hareketleri tarafından uygulanan zorlamalı titreşimlere maruz kalır. Yapının ataleti, temel hareketlerine direnme eğilimindedir. Bu nedenle, temel olarak, deprem esnasında bir kesme kuvveti (base shear) oluşacaktır. Bu güç şuna eşittir; deprem sırasındaki boş olan silindirik çelik yapılarda Şekil 3'de görüldügü gibi, yanal bir kuvvet (F) yapının ağırlık merkezinde yatay olarak hareket eder ve temelin ters yönünde eşit bir kayma yapar. Deprem kuvveti aşağıdaki formül ile kolayca hesaplanabilir.

$$
F=W * \frac{a}{g}
$$

$\mathrm{F}=$ Deprem Kuvveti ( base shear )

W = Yapının ağırlı̆̆

$\mathrm{a}=$ Deprem ivmesi

$\mathrm{g}=$ Yerçekimi kuvveti

$\frac{a}{g}=$ Sismik faktör

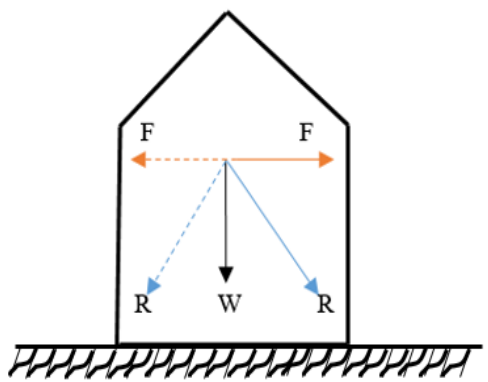

Şekil 3. Deprem esnasında sismik yapı (Seismic structure during the earthquake)

Öte yandan, silo tahıl tanecikli malzemeyle doluyken, deprem esnasındaki dinamik davranışları çok karmaşık yapıya bürünüyor. Yarıçapı R olan ve $\mathrm{H}$ yüksekliğine kadar tane benzeri materyalle doldurulmuş Şekil 4. teki gibi düztabanlı bir tahıl silosunun geometrisi ve referans sistemi benimsenmiștir. Burada, tanenin serbest yüzeyinin yatay olduğu varsayılır.

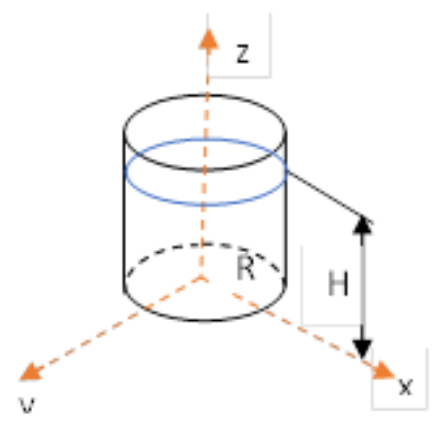

Şekil 4. Düztabanlı tahıl silosunun geometrisi ve referans sistemi (Geometry and reference system of flat bottom grain silo) 
Tahıl benzeri malzemelerin deprem ivmesi nedeniyle silo duvarlarında ürettiği basınçların yaklaşık bir tahminini elde etmek amacıyla idealize edilmiş bir sistem kullanılır. Buna göre, Şekil 5'te iç diskin ve dış simidin boyutları, tahılın serbest yüzeyinden ölçülen z mesafesine göre belirlendiği için dış simidin kalınlığı (s), z tarafından değişir. İç disk $\mathrm{D}$, bir $\mathrm{d}_{\mathrm{z}}$ yüksekliği ve bir yarıçap $\mathrm{r}(\mathrm{z})$ = R-s $(\mathrm{z})$ ile tanımlanır ve tahılın serbest yüzeyinden ölçülen $\mathrm{z}$ derinliğine, yani zeminden $\mathrm{h}=\mathrm{H}-\mathrm{z}$ yüksekliğine kadar ölçüldüğü varsayılmaktadır. Dıș simit, her biri merkez açısı $\mathrm{d} \theta$ olan sektörlere (dairesel halka şeklinde) alt bölümlere ayrılmıştır, Şekil 4.'de belirtildiği gibi, x'in negatif yarı ekseninden saat yönünde ölçülen merkezi açı $\theta$ ile tanımlanır. Dış simidin her kesimi, bir dz yüksekliği ve s (z) kalınlığı ile karakterize edilir. Yatay düzlemde bir yardımcı koordinat sistemi $(0, \xi-\eta)$ de tanımlanmıştır, burada $\xi$ radyal yönü (silonun yan yüzeyine dik) ve $\eta$, Şekil 4'te gösterildiği gibi $\xi$ ile dik yönü temsil eder. Yukarıda tarif edilen idealize edilmiş sistem, Şekil 5'te Silvestri ve vd. tarafından, idealize edilmiş koşullarda incelenmiştir. Deprem yer hareketi, genel olarak t zamanının ve h yüksekliğinin (veya eşdeğer olarak, Şekil 5'de gösterildiği gibi, tahılın serbest yüzeyinden z mesafesinin) zamanın bir fonksiyonu olarak dikey ve yatay ivmelenmelerle simüle edilir.

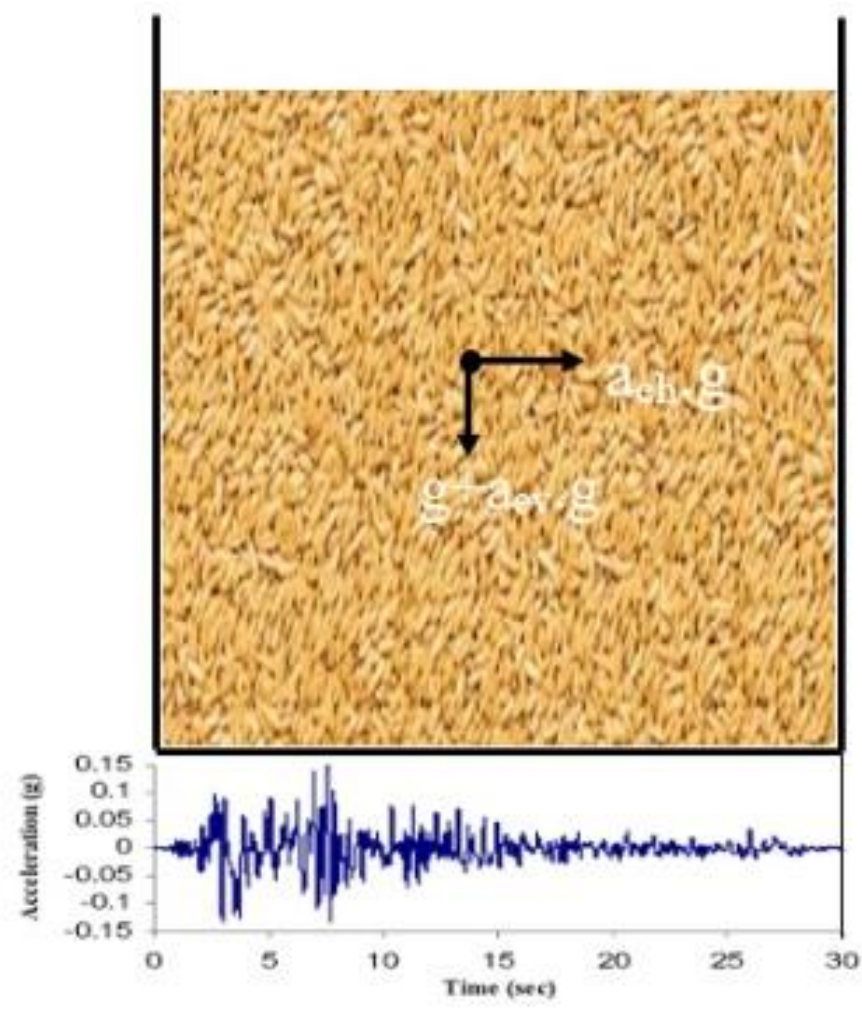

Şekil 5. İvmelenmiş koşullarda: silo g+a $\mathrm{a}_{\mathrm{e}} \mathrm{g}$ ve $\mathrm{a}_{\mathrm{eh}} . \mathrm{g}$ maruz kalır (In accelerated conditions: silo g+aev.g and aeh.g are exposed)

Şekil 6.'da düşey doğrultu söz konusu olduğunda, silonun ve içeriğinin yaşadığı mutlak ivmelenme, $a_{v}(t, z)=g+$ $\mathrm{a}_{\mathrm{ev}}(\mathrm{t}, \mathrm{z}) \cdot \mathrm{g}$, olarak verilir, g burada yerçekimi ivmesidir ve $\mathrm{a}_{\mathrm{ev}}(\mathrm{t}, \mathrm{z}) \cdot \mathrm{g}$, depremden kaynaklanan ek dikey ivmelenme olarak verilir. Yatay doğrultuda, mutlak ivme $a_{h}(t, z)=a_{e h}(t, z) \cdot g$, burada, $a_{e h}(t, z) \cdot g$, depremden kaynaklanan yatay ivmedir. Hem aev hem de ae, g'nin fraksiyonları olarak ifade edilir. Karşılaştırmalı amaçlar için, Eurocode 8 Part 4 §3.3 (EN 1998-4 2006), a (t, z) parametresine a (z) olarak atıfta bulunur; bu, silonun depolanan içeriğin eşdeğer yüzeyinden dikey bir mesafedeki z yatay tepkisine oranının yerçekimi ivmesine oranı olarak tanımlanır.

Deprem girdisindeki zamanın değişimi söz konusu olduğunda, deprem yer hareketi zamanı(t) sabit dikey ve yatay ivme ile simüle edilir: $\mathrm{a}_{\mathrm{ev}}(\mathrm{t}, \mathrm{z})=\mathrm{a}_{\mathrm{ev}}(\mathrm{z})$ ve aeh $(\mathrm{t}, \mathrm{z})=\mathrm{a}_{\mathrm{eh}}(\mathrm{z})$. Bu varsayımın, hem dikey hem de yatay ivmelerin eşzamanlı olarak en yüksek değerlerine ulaşması gerektiğini kurgusal bir zaman dilimini temsil ettiği düşünüldügünde, daha güvenli ve basitleştirmeye yol açtığı açıktır. Aynı varsayım, zamanın bir fonksiyonu olmayan $\alpha$ (z) parametresi ile Eurocode 8 Part 4 §3.3 (EN 1998-4 2006) tarafından da kabul edilmiştir. 
(a)

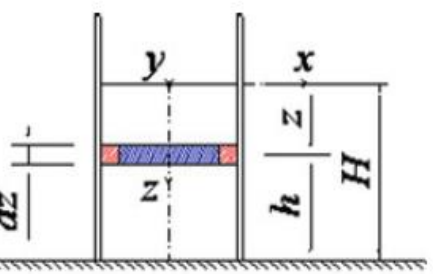

(b)

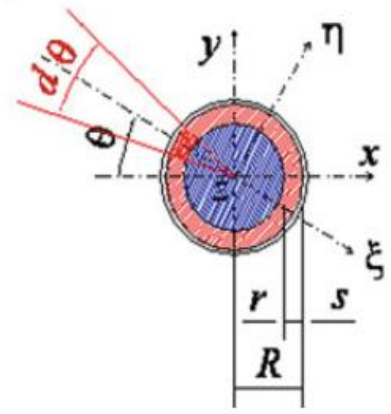

Şekil 6. Tanenin dış simidi (kırmızı tarama) ve iç diski (mavi tarama), dikey bölüm, b planı görünümü (Outer wheel of the grain (red hatching) and inner disk (blue hatching), vertical section, plan b view)

\section{Düztabanlı Siloların Sismik Tasarım Teorisi ve Tasarım Hükümleri Detayı (Detail of Seismic Design Theory and Design Provisions of Flat Bottom Silos)}

Türkiye'de en yaygın kullanılan silo tipi, yerden destekli düztabanlı tahıl depolama silolarıdır. Buradan yola çıkarak, özellikle düztabanlı silolar hakkında yapılmış teorik çalışmalar ve tasarım hükümlerinin genel değerlendirilmesi bu bölümde detaylandırılmaktadır.

\subsection{Janssen (1895) ve Koenen (1896) Teorisi (Janssen (1895) and Koenen (1896) Teory)}

Tahıl benzeri malzeme içeren siloların duvarlarındaki dikey ve yatay basınçların gerçek dağılımını tahmin etmeyi amaçlayan ilk model, on dokuzuncu yüzyılın sonlarında Janssen (1895) ve Koenen (1896) tarafından yapılan çalışmalara dayanmaktadır. Duvara yaslanan etkili tahıl kütlesini değerlendirmek ve statik durum için güvenli tasarım göstergeleri sağlamak amacıyla, tahıl içermeyen yüzeyden, pv(z) 'e kadar olan normal bir mesafedeki dikey tane-tane basıncı kabul edilir. Bu varsayım, duvardaki yatay ve dikey kuvvetlerin eksenel-simetrik dağılımına yol açar. Janssen denklemleri, uzun zamandır duvardaki normal basınçların, düşey basınçların ve akış sırasındaki değerlerin tahmin edilebileceği duvardaki sürtünme kuvvetlerinin hesaplanmasında uygun bir araç olarak kullanılmıştır. Silo duvarındaki yüklerin tasarım değerleri böylece, akış yükü çarpanları veya Janssen basınçlarına uygulanan aşırı basınç faktörleri kullanılarak elde edilir.

$$
\begin{aligned}
& P_{o}(Z)=\lambda \cdot P_{v}(Z) \\
& \tau_{o}(Z)=\mu_{G W}(Z) \cdot P_{o}(Z)
\end{aligned}
$$

Burada, $P_{o}(Z)$ normal yatay basınç, $\lambda$ basınç oranını (yatay ve düşey basınçlar arasında), $\tau_{o}(Z)$ düşey sürtünme gerilimini ve $\mu_{G W}$ tane-duvar sürtünme katsayısını ifade ediyor. Temel bir tahıl tabakasının düşey kuvvet dengesi dikkate alındığında (birinci mertebeden diferansiyel denklem), genel yükseklik z silo duvarında ısrar eden normal yatay basınç $P_{o}(Z)$ 'nin üssel formunu verir;

$$
P_{o}(Z)=\frac{\gamma \cdot R}{2_{\mu_{G W}}}\left[1-e^{-2 \frac{z \cdot \mu_{G W} \cdot \lambda}{R}}\right]
$$

$\gamma$, silo içindeki malzemenin özgül ağırlığıdır ve R, silonun yarıçapıdır. Șekil 7'de, Janssen ve Koenen tarafından önerilen; fiziksel olarak idealize edilmiş modele göre, tahıl ve duvarın statik şartlarda etkili basınç dağılımını göstermektedir. Solda a)'daki düş̧ey kesite göre kuvvetler taneye yönlendirilir. Sağ tarafta, b)'deki yatay kesite göre, soldaki taneye ait kuvvetler, duvarın sağına yönlendirilir.

Jamieson (1903), Amundson (1945), Negi ve diğerleri (1977), Schwab ve diğerleri (1994), Vanel ve diğerleri (2000), Ovarlez ve diğerleri (2003), Tatko ve diğerlerinin yaptı̆̆ deneysel kanıtlar gibi (Amundson, 1945; Jamieson, 1903; Ovarlez, Fond, \& Clément, 2003; Schwab, Ross, White, \& Colliver, 1994; Tatko \& Kobielak, 2008; Vanel ve vd., 2000); Kobielak (2008) ve Rotter ve vd. (1998), Landry ve vd. (2003) yaptığı sayısal parçacık simülasyon da, böyle bir ifadeyi onaylamaktadır (Landry, Grest, Silbert, \& Plimpton, 2003; Rotter, Holst, Ooi, \& Sanad, 1998).

Pieraccini, ve diğerlerine göre (2015), Janssen ve Koenen tarafından önerilen modelin uygulanması, sistemin eksenel simetrisi artık geçerli olmadığından, dinamik (örneğin hızlandırılmış) şartlarda uygulanamaz (Butenweg ve vd., 2017). 


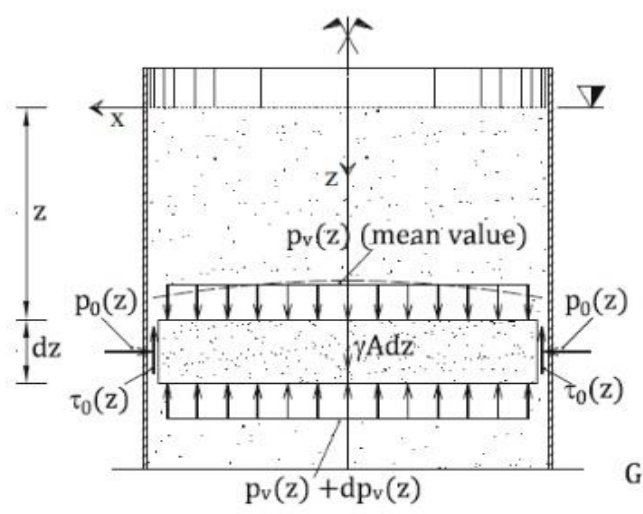

(a)

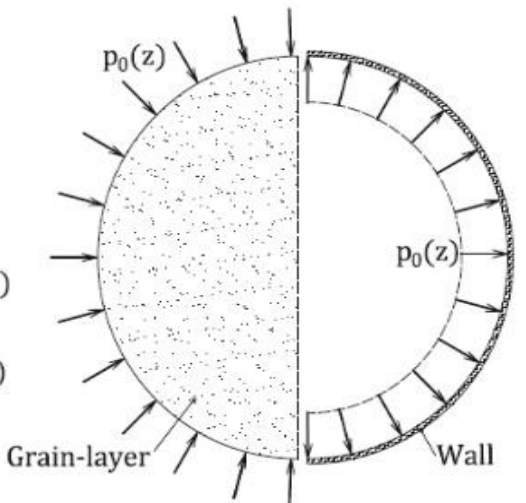

(b)

Şekil 7. Statik koşullar için Janssen (1895) ve Koenen (1896) teorisinin fiziksel idealize modeli (Physical idealized model of Janssen (1895) and Koenen (1896) theory for static conditions)

\subsection{Trahair'nin (1983), Formülsayon Metodu (Formulation method of Trahair (1983))}

Trahair ve vd. (1983), tarafından önerilen analitik formülasyon dinamik (acceleration) koșullarda silo çeperi üzerinde etkili olan ek tahıl, basınç dağılımının en eski kapalı form tahminini temsil etmektedir. Bu formülasyon, depolanmış tanenin her yatay katmanının doğrudan duvar çevresine eşit bir şekilde doğrudan bir duvar yükü uyguladığı varsayımına dayanır. Bu yük, bütün depolanan içeriğin katı bir vücut hareketinin sonucudur (Trahair, Abel, Ansourian, Irvine, \& Rotter, 1983). Rotter ve Hull'a (1989), göre bu formülasyon, yatay tane-tahıl sürtünme gerilmeleri yoluyla tabana yük transferini dikkate almaz ve dikey tane-duvar sürtünme gerilmelerini görmezden gelir (Rotter \& Hull, 1989).

$\mathrm{Bu}$ varsayımlar, eylemsizlik kuvvetlerini dengelemek için silo duvarında etkili olan radyal ve çevresel ek basınçların sırasıyla $\Delta_{P n G W}(\vartheta)$ ve , $\Delta_{P \vartheta G W}(\vartheta)$ çok basit, koruyucu ifadelerine yol açar:

$$
\begin{aligned}
& \Delta_{P n G W}(\vartheta)=\frac{\alpha_{g \cdot \gamma \cdot R \cdot \cos (\vartheta)}}{2} \cdot f \\
& \Delta_{P \vartheta G W}(\vartheta)=\frac{\alpha_{g \cdot \gamma \cdot R \cdot \sin (\vartheta)}}{2} \cdot f
\end{aligned}
$$

Burada $\alpha_{g}$ sabit yatay ivmenin yerçekimi ivmesine, yani g' ye oranıdır, $\vartheta$, yatay ivmenin yönüne göre enlemdir ve f, silonun narinlik oranına bağlıdır: eğer kısa silolar için $H / R>1$ olursa tane özelliklerinin silo duvarına etkiyen aşırı basınç dağılımları üzerindeki etkisi göz önünde bulundurulmaz (birim ağırlık hariç, $\gamma$ ).

\subsection{Veletsos ve Younan'ın Dinamik Model Yaklaşımı (1998) (Dynamic Model Approach of Veletsos and Younan (1998))}

Veletsos ve Younan (1998) tarafından yapılan analitik çalıșma özellikle dinamik koșullarla (acceleration) ilgilidir. Silindirik dikey bir silonun, sismik hareketin uygulandığı sert bir tabana sabitlendiği varsayılmaktadır. Depolanmış malzemenin (malzeme homojen viskoelastik bir bütün olarak modellenmiştir) silo çeperiyle etkileşime giren bir konsol kesme kirişi gibi davrandığı varsayılmaktadır. Tahıl duvarı sürtünmesini modellemek için iki sınır koşulu göz önünde bulundurulur; bunlar pürüzsüz ve pürüzlü arayüzdür. Hem çalkalanma modu hem de kısmi granüler içeriğin dikey yerleşimi, sismik eylemlerin değerlendirilmesinde hesaba katılmaz ve dikey ivmelenme göz önünde bulundurulmaz. Teori hem sağlam hem de esnek duvarı ele alır ve sismik eylemlerin değerlendirilmesindeki ataletlerini açıklar.

Depolanmıș ortam için hareket denklemlerinden yola çıkarak, sabit hızlanma, harmonik uyarma ve deprem durumlarında, dinamik duvar basınçlarının (normal ve teğetsel), taban kayma, taban bükülme momentlerinin ve silo temelinde indüklenen yer hareketinin kapalı formda tahmin edilmesi sağlanır. Tüm durumlar için, etkili kütle tanımlanmıştır. En sade durumda, kaba arayüzü olan sert silo duvarlarından biri olarak ortaya çıkıyor. Eurocode 8 tarafından sağlanan mevcut tasarım kuralları bu formülasyona dayanmaktadır.

\subsection{Eurocode 8 hükümleri (2006) (Eurocode 8 provisions (2006))}

Siloların sismik tasarımı için en geçerli Eurocode 8 hükümleri (2006) aşağıdaki araştırmacıların çalışmalarına dayanmaktadır: Younan ve Veletsos (1998) tarafından önerilen ve analitik formülasyon metodu, sadece en güvenli koşulları göz önüne alarak (kaba sert arayüzlü silo duvarı), Rotter ve Hull (1989) tarafından yapılan sayısal 
araştırmaya dayanmaktadır. Öte yandan, Veletsos ve Younan (1998) tarafından elde edilen sonuçlar, gerçek duvar esnekliğinin göz önüne alınmasının, özellikle 0.1-0.5 sn arasındaki sürede etkili kütlenin önemli ölçüde azalmasına yol açabileceğini göstermektedir (Veletsos \& Younan, 1998). Fiili Eurocode 8 hükümlerinde, ek normal basınç dağılımının orijinal formülasyonu, pratik olarak tekdüze boyuna bir profil (H/R'nin narinlik oranının fonksiyonu) ve bunun tepkime hızının oranını temsil eden bir büyütme faktörü cinsinden verilmiștir. Duvar ataleti, sismik işlemlerin değerlendirilmesinde (hem çelik hem betonarme silolar için) ihmal edilir. Çeşitli faktörlerin (basınç oranı, tane çeperi ve tane dibi sürtünme katsayıları vb.) yönettiği karmaşık tahıl-silo etkileşimi, sisteme etki eden sismik kuvvetlerin bu değerlendirmesinde hesaba katılmaz.

Etkili kütlenin, doğrudan zeminden desteklenmiş silolar ve yüksek silolar için ortak narinlik oranı değerleri için toplam depolanmış ürünün \%75 ile \%95 aralığında sonuçlandığını göstermektedir. Benzer şekilde, Eurocode 8, ACI 313-97 (1997) tarafından önerilen basitleştirilmiş yöntem, tahıl kütlesinin asıl hacminin merkezine bağlı olan atalet kuvveti ile depolanmış içeriğin \%80'ine (hem desteklenmiş hem de yükseltilmiş silolar için) eşit etkili bir kütle olarak görmektedir.

\subsection{Silvestri Teorisi (Silvestri Teory)}

Hem statik hem de dinamik (acceleration) koşullar altında tahıl benzeri malzeme içeren yerden destekli düztabanlı silolarının duvarındaki basınç dağılımının değerlendirilmesi için analitik bir formülasyon, Silvestri ve vd. (2012) tarafından yakın zamanda önerilmiştir. Silvestri'nin teorisi olarak. Janssen ve Koenen tarafından statik durum için orijinal olarak tanımlanan ve eksenel simetri eksikliğinden kaynaklanan sorunların üstesinden gelmek için Pieraccin ve vd. (2015) tarafından modifiye edilerek yeni bir fiziksel model geliştirilmiştir. Pieraccin ve vd., Silvestri teorisini aşağıdaki gibi özetlemişler.

1. Silo duvarının, Janssen ve Koenen tarafından da varsayıldığı gibi dikey yönde eksenel olarak sonsuz ve sert olduğu varsayılmaktadır.

2. Tahıl-duvar sürtünmesinin, Janssen ve Koenen tarafından da varsayıldığı gibi, tamamen kullanılması gerektiği varsayılmaktadır.

3. Şekil 8 de gösterilen Janssen ve Koenen teorisinin idealize modeli Silvestri tarafından geliştirilerek, her bir tahıl tabakası iki parçaya bölünmüştür: (i) aşağıdaki tabakalara tamamen yaslanmış olan tahıl (orta kısım, disk D) ve (ii) duvar tarafından sürtünme ile tamamen tutulan tahıl (dış simit, eleman E). Bu bölünmüşlük benzetimi Şekil 8. de dikey ve yatay bölümlerde gösterilmektedir.

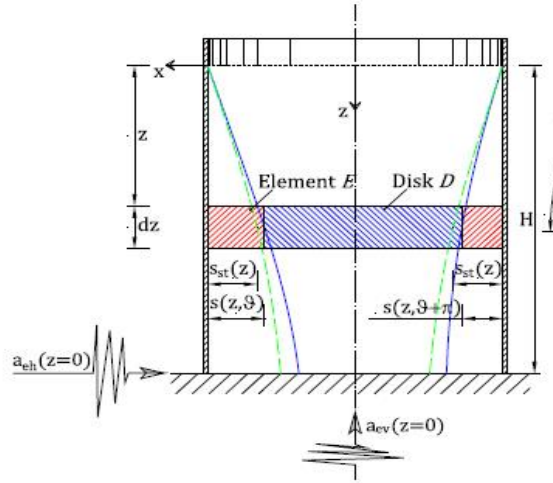

(a)

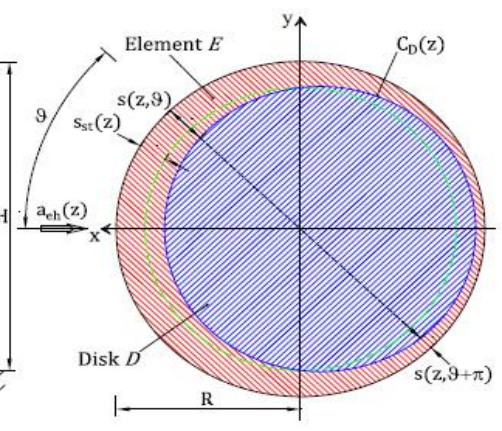

(b)

Şekil 8. Dış simit (kırmızı tarama) ve tane tabakasının iç diski (mavi tarama). a) dikey kesit, b düz görünüm (Outer toros (red hatch) and inner disk of the grain layer (blue hatch) a) vertical section, b flat view)

4. Disk D, Janssen ve Koenen idealize modelinde varsayıldığı gibi $\mathrm{P}_{\mathrm{v}, \mathrm{GG}}(\mathrm{z})$ 'e eşit olarak dağıtılmış dikey basınçlar sunar.

5. Eurocode 8 tarafından öngörülenlerin aksine, yatay tahıl-tahıl sürtünme gerilmelerinin $\left(\tau_{o}\right.$, GG) sıfırdan farklı olduğu ve bu nedenle dengede olduğu varsayılmıştır. Bunlar, düşünülen temas yüzeyindeki sürtünme yasasıyla sinirlidir.

6. Ayrica $\tau_{v} \mathrm{GW}, \tau_{h} \mathrm{GW}$ ve $\tau_{h} \mathrm{~GB}$ sürtünme gerilmeleri (burada $\mathrm{v}=$ dikey, $\mathrm{h}=$ radyal yatay, $\mathrm{G}=$ tane, $\mathrm{W}=\mathrm{duvar}$ ve $\mathrm{B}$

= alt) dengede olacak şekilde göz önünde bulundurulur ve temas yüzeyindeki sürtünme yasasıyla sınırlandırılır.

7. Serbest yüzeyin çok altındaki katmanlarda ve silonun tabanında yatay D disk kayması meydana gelmez.

8. Zaman sabiti dikey ve yatay ivmelenmeler $\mathrm{a}_{\mathrm{ev}}(\mathrm{z})$ ve $\mathrm{a}_{\mathrm{eh}}(\mathrm{z})$ siloya etki eden deprem yer hareketini simüle etmek için kullanılır.

9. Zaman sabiti dikey ve yatay ivmeler aynı anda uygulanır. 
10. Silo duvarının atalet katkıları dinamik koşullarda ihmal edilir. Ayrıca, çalkalama modunun, üst tanecik katmanlarının yatay kaymasının ve tanecik dikey yerleşimlerinin etkileri dikkate alınmamıştır.

11. İki sınır koşulunun dayanım zarfı, ardışık katmanlar arasında E elemanı içindeki farklı dikey normal basınç dağılımları $\mathrm{P}_{\mathrm{v}}, \mathrm{GG}(\mathrm{z})$ dikkate alınarak alınır.

Şekil 9, Silvestri ve vd. (2012), önerdiği fiziki idealize edilmiş modele göre, dinamik (acceleration) koşullarda tahıl ve duvar üzerindeki etki dağılımını göstermektedir. a) Dikey bir enine kesitte gösterildiği gibi kuvvetler taneye yönlendirilir. b) Yatay kesitte görüldüğü gibi, soldaki taneye ait kuvvetler, duvarın sağına yönlendirilir.

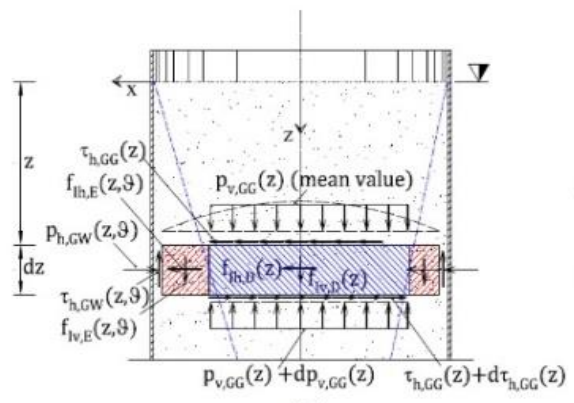

(a)

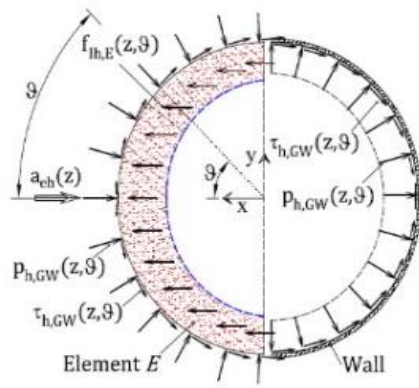

(b)

Şekil 9. Dinamik (Acceleration) koşullar için Silvestri'nin teorisinin (2012) fiziksel idealize modeli (Physical idealized model of Silvestri's theory (2012) for dynamic (Acceleration) conditions

Silvestri'nin, tahıl benzeri malzeme içeren siloların dinamik davranışlarının analitik çalışması, Pieraccini ve vd. tarafından (2015) teorik bir çerçeveye göre geliştirilmiştir (Refined). Orijinal teoride yapıldığı gibi, dinamik (acceleration) şartlardaki denge, sırasıyla yatay ve dikey doğrultular boyunca iki zaman sabiti ivmelenme bileșeni $\mathrm{a}_{\mathrm{eh}}(\mathrm{z})$ ve $\mathrm{a}_{\mathrm{ev}}(\mathrm{z})$ tarafından oluşturulan ek dinamik etkilerden sorumludur. Daha sonra, basit düz dinamik denge denklemleriyle, silo ve tahıl arasında değiş tokuş edilen basınç dağılımı analitik olarak tanımlanır. En sonunda, türev sonucu olarak, taban duvar kayması ve eğilme momenti, elverişli entegrasyonlarla hesaplanır.

Pieraccini ve vd., Şekil 10'daki fiziksel olarak idealize edilmiş modellerin görsel karşılaştırmasını yapmışlardır. İlk satırda dikey kesit, ikinci satırda yatay kesit görülmektedir. a) Statik koşullar için bir Janssen (1895) ve Koenen (1896) teorisini, b) Silvestri teorisini (2012) ve c) Dinamik (acceleration) koşullar için refine teorisini göstermektedir (2015).

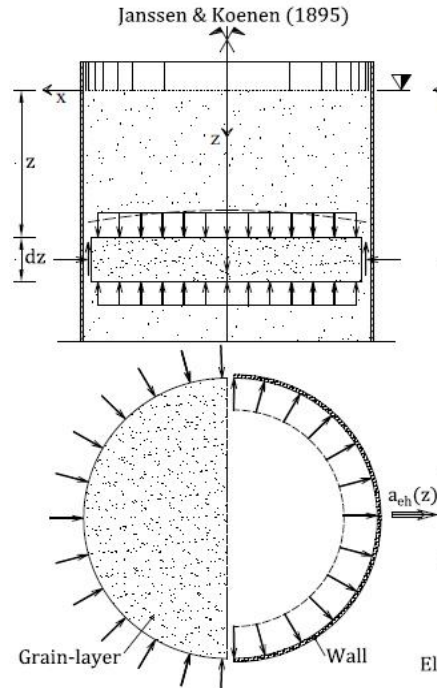

(a)

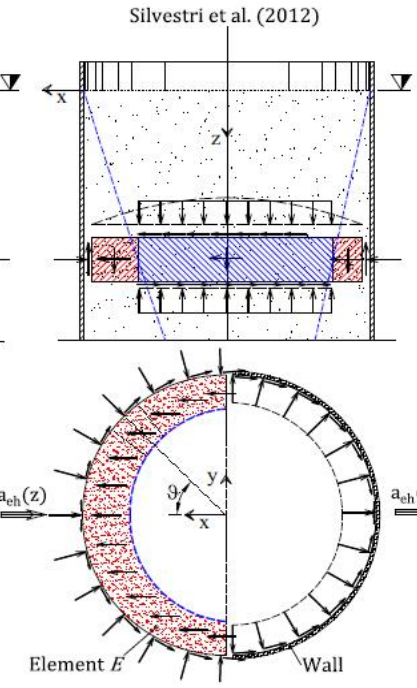

(b)

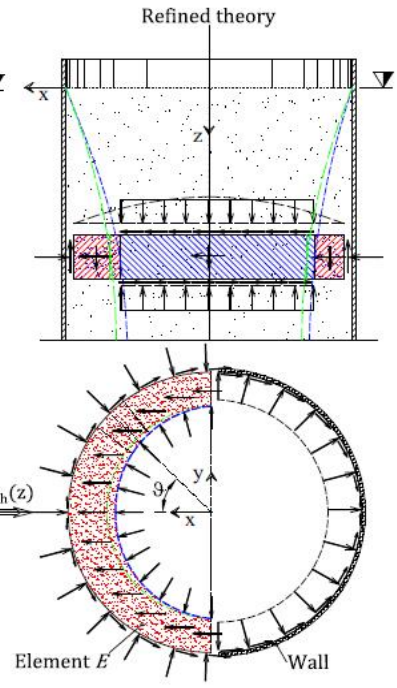

(c)

Şekil 10 Fiziksel idealize edilmiş modellerin görsel karşılaştırması (Visual comparison of physically idealized models)

Şekil 11 ve 12, disk D, eleman E ve silo duvarın dinamik koşullarda değiş tokuş ettiği karşılıklı eylemi göstermektedir. Karşılaștırma amacıyla Silvestri ve vd. (2012) tarafından takip edilen aynı gösterim ve aynı kavramsal yapı, güncellenmiş teorinin analitik gelişimi içinde benimsenmiştir. 


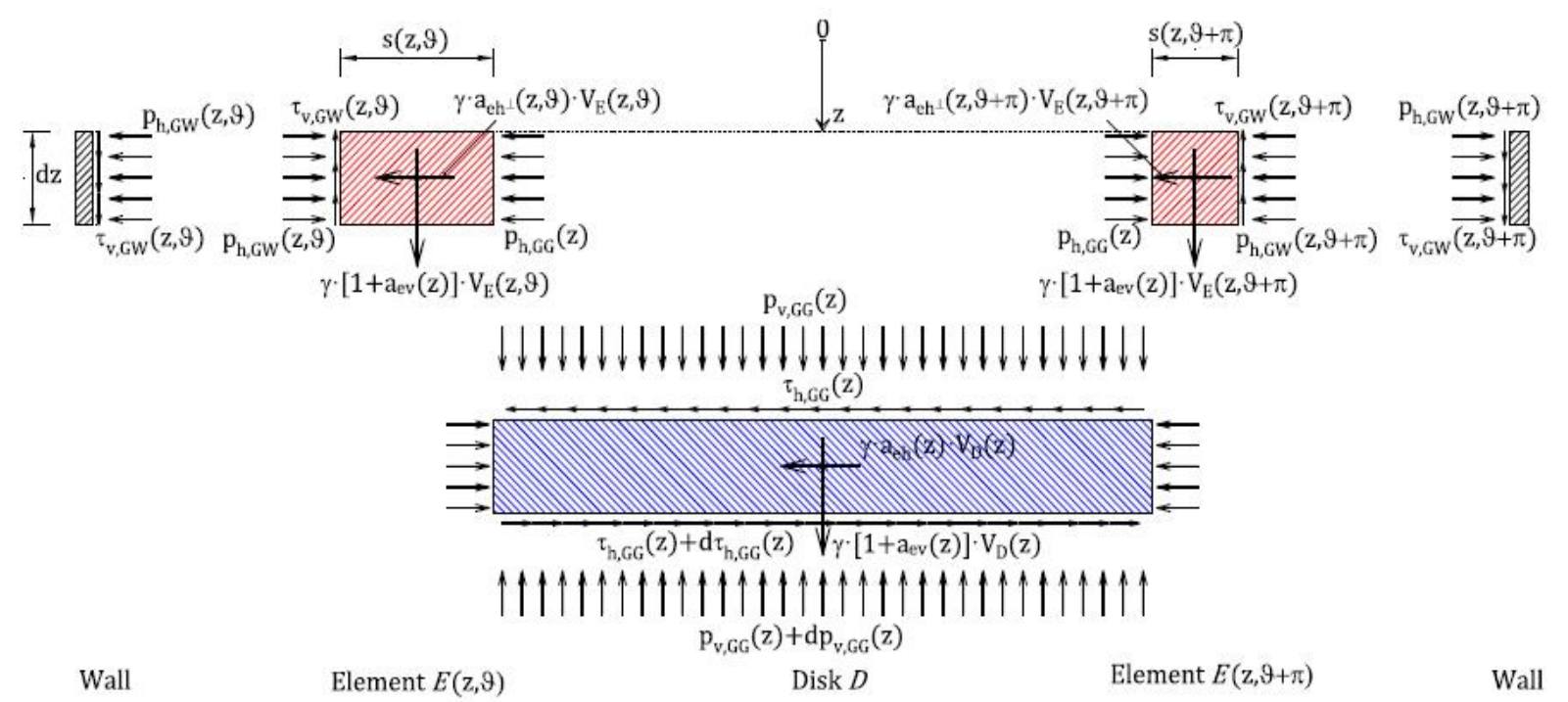

Şekil 11. D ve E elemanlarında dikey ve yatay çalışma hareketleri (Vertical and horizontal movements in D and E elements)

Dinamik koşullarda disk D'nin dikey kuvvet dengesi sağlaması.

$$
P_{v} \mathrm{GG}(Z) \cdot \mathrm{AD}_{\mathrm{D}}(Z)+f_{\mathrm{I} v}, D(Z)-P_{v} \mathrm{GG}\left(Z+d_{Z}\right) \cdot \mathrm{AD}_{\mathrm{D}}(Z)=0
$$

Burada C1, sınır koșulu uygulayarak elde edilebilecek bir entegrasyon sabitidir (tanenin üst yüzeyinde dikey basınçlar boștur, yani pv,GG $(\mathrm{z}=0)=0)$.

E elementinin temel bir sektöründe faaliyet gösteren yatay hareketler Şekil 12. de gösterilmiştir.

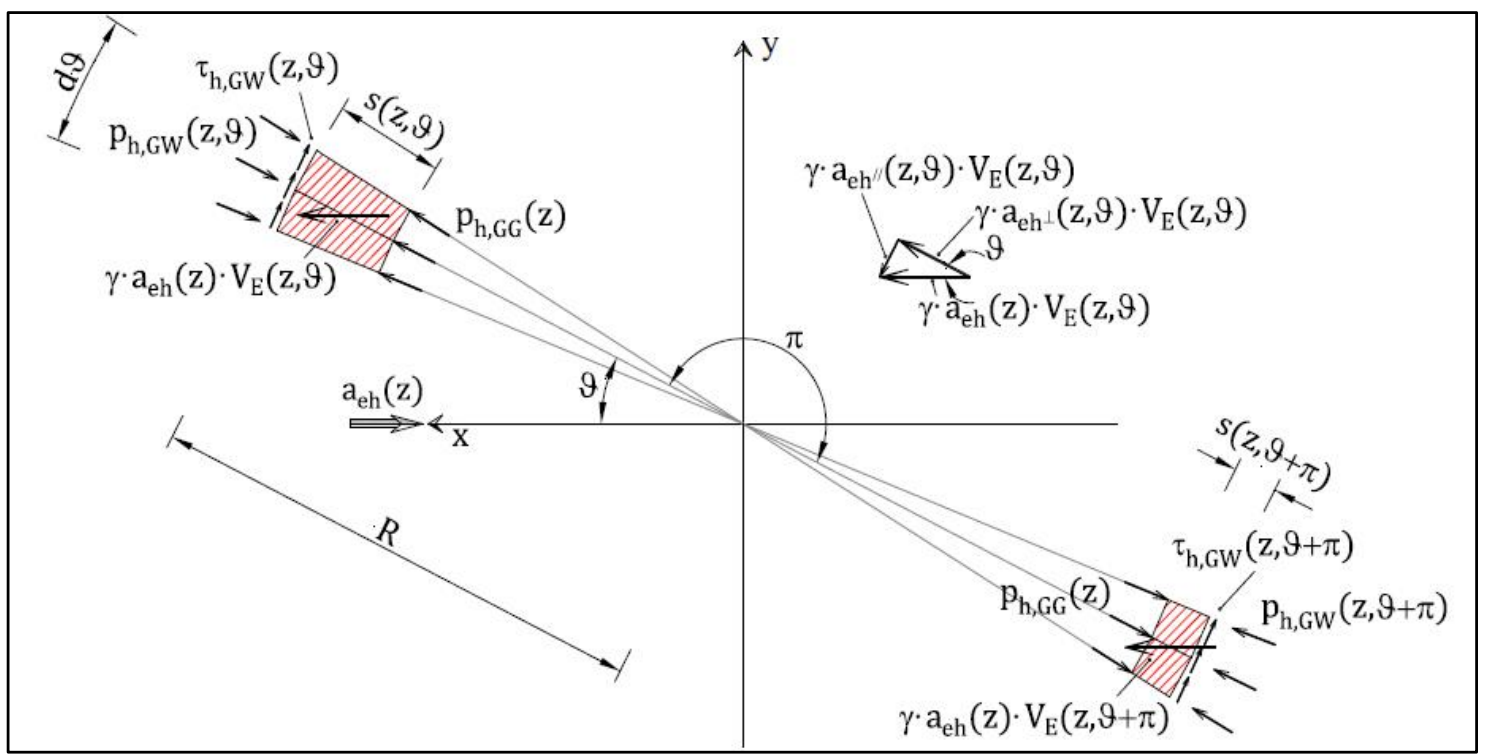

Șekil 12.Yatay kesit: E elementinin temel bir sektöründe faaliyet gösteren yatay hareketler (E) (Horizontal section: Horizontal movements operating in a basic sector of element (E))

\section{Pieraccini'nın Uygulama Örnekleri ve Tartışma (Applications of Pieraccini and Discussion)}

Bu bölümde Pieraccini'ni ve vd. yaptığı (2015) rafine teorisine göre, Janssen ve Koenen teorisi ile Silvestri'nin teorisi, Trahair formülasyonu ve Eurocode 8 hükümleri arasında kısa bir karşılaştırma uygulamalı örnekler yoluyla sunulmaktadır. Karşılaştırma hem statik hem de hızlandırılmış koşullarda (tane yatay ve dikey ivmeler için sabit bir dikey profil varsayarsak), tane duvarı basınçları, duvar kesme ve eğilme momentleri açısından yapılır. 


\subsection{Statik Koşullarda Basınç (Pressure in Static Conditions)}

$\mathrm{Bu}$ bölümde, Janssen ve Koenen teorisi, Silvestri teorisi ve rafine teorisi tarafından sağlanan tane-duvar basınçlarının boy profilleri sunulmaktadır. Şekil 12, farklı uzunluk oranları (Malhotra 2000'deki düşük, ortalama, yüksek modele göre) ve $\gamma=15,000 \mathrm{~N} / \mathrm{m}^{3}, \mu \mathrm{GW}=0,45$ ve $\lambda=0,70$ ile karakterize edilen üç silo için basınç profillerini rapor etmektedir (Malhotra, 2000). Tahıl-duvar basınçları, temel yatay geostatik tanecik-tanecik basıncı, yani $\lambda$, $\gamma$ ve H'a göre normalleştirilmiştir.

Rafine formülasyon, konsolide Janssen ve Koenen formülasyonlarını iyi bir uyum ile eşleştirebilir. Öte yandan, Silvestri'nin teorisinin narinlik oranına bağlı olmayan doğrusal bir dağılım sağladığı gösterilmiștir. Silvestri'nin teorisinin ve rafine teorisinin Janssen ve Koenen formülasyonu ile karşllaștırmalı olarak sunularak, Formül (4) de belirtildiği gibi, tahıl-duvar basınçlarının üssel fonksiyonunun farklı bir yaklaşım seviyesine uzanır. Üstel fonksiyonunu Taylor Serileri vasitasiyla $e^{-a}=1-a+\frac{a^{2}}{2}+O\left(\mathcal{E}^{3}\right)$ olarak ifade ederek, burada $a=\frac{2 \omega(z)}{R}$ değerinde, sırasıyla Janssen ve Koenen formülünün birinci ve ikinci mertebe yaklaşımları ortaya çıkar.

Denklem (10) z için doğrusaldır. Silvestri'nin teorisinin statik koşullarda boş kalınlıkta $\mathrm{S}_{\mathrm{st}}(\mathrm{z}) \mathrm{sağladı̆̆}_{1}$ düşünüldügünde, tane-duvar basınçları, D diskine etki eden yatay tane-tane geostatik basınçlarına eşit olur. Bu eğilim, tahıl içermeyen serbest-yüzeye karşılık gelen Janssen ve Koenen formülasyonunun eğimiyle eşleşir.

$$
P_{h}, G W(z)_{I^{0}}=\lambda \cdot \gamma \cdot z
$$

Janssen (1895) ve Koenen (1896) teorisi, Silvestri teorisi (2012) ve rafine teori statik koşullarda: a) H/R = 0,50 b) $\mathrm{H} / \mathrm{R}=1,00$ ve c) H/R = 2.00 karşılaştırmalı olarak, normal basınç dağılımları Şekil 13.'desunulmuştur.

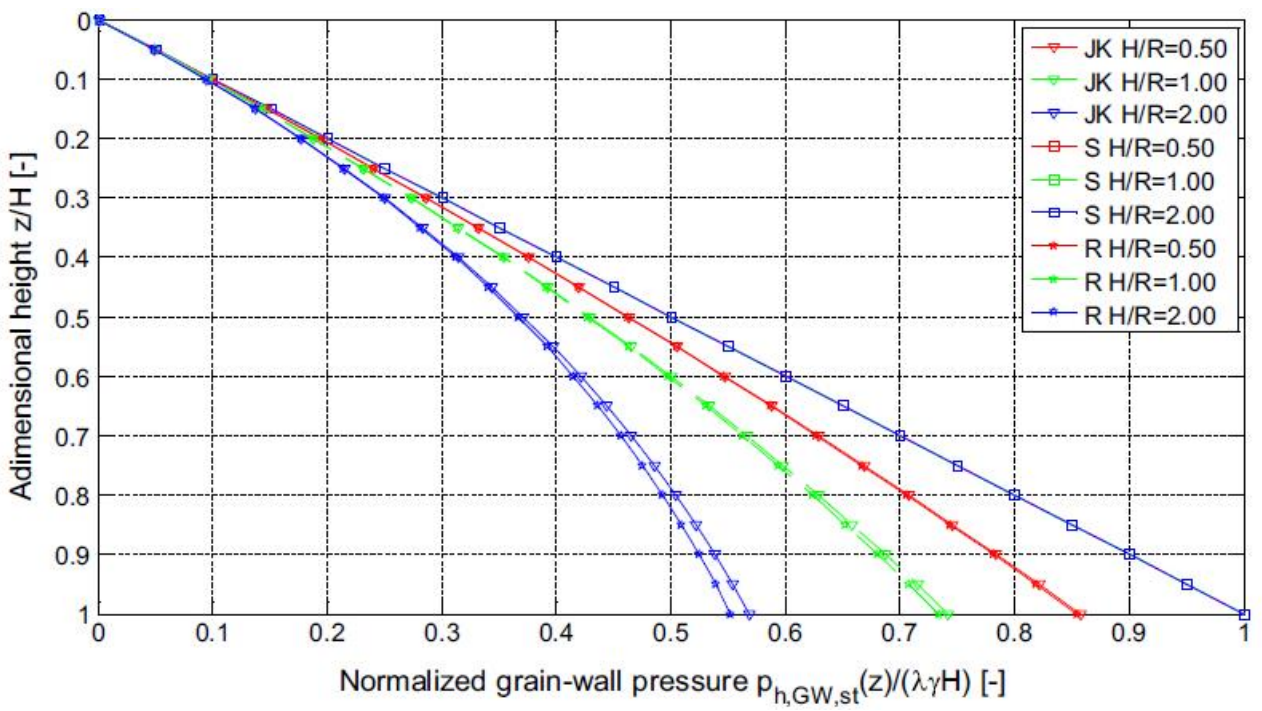

Șekil 13. Normalize edilmiș tahıl duvarında normal basınçlarının boyuna değișimi (Longitudinal changes of normal pressures in normalized grain wall)

Denklem (11) $z$ cinsinden kareseldir. Silvestri'nin teorisinin aksine, rafine teori statik koșullarda boş olmayan bir kalınlık st $(z)$ kabul eder. Farklı fiziksel idealleşmeler, yani Janssen ve Koenen teorisi için benzersiz bir tahıl katmanı sayesinde, rafine teori için iki farklı bölüme (D ve E) karşı, kalınlık Sst(z) ile ilgili olarak göz ardı edilebildiği zaman sonuçlar benzerlik gösterebilir. Sonra yarıçap R'ye kadar E elemanı incelir ve disk D pratik olarak tüm A kesiti ile çakışırsa, iki fiziksel model tam olarak eşleşir. Bununla birlikte, aynı zamanda, $\mu \mathrm{GW}, \lambda$ ve $H / R$ parametrelerinin daha yüksek değerleri için yaklaşık değer ihmal edilebilir görünmektedir.

$$
P_{h}, G W(z)_{I I^{0}}=\lambda \cdot \gamma \cdot z \cdot\left[1-\frac{\omega(z)}{R}\right]
$$

Boş tahıl duvarı sürtünme katsayısı olması durumunda, rafine teori tarafından sağlanan tahıl-duvar basınçlarının büyüklüğü ve yükseklik boyunca profilinin Rankine teorisiyle (1857) eşleștiği belirtilmelidir (Rankine, 1857). Hirshfeld ve Rapaport 2001; Landry ve vd. (2003) göre basınç Janssen analizinde beklendiği gibi, $\lambda$ oranı Rankine'nin aktif toprak basıncı katsayısı olur (Hirshfeld \& Rapaport, 2001; Landry ve vd., 2003). 


\subsection{Dinamik Koşullarda Basınç (Pressure in Dynamic Conditions)}

Silvestri'nin teorisi ve rafine teorisi, hem şekil hem de hacim olarak hızlandırılmış koşullarda $V_{E, d y n}(z)$ ve $V_{D}$,dyn( $(z)$ hacimlerinin farklı formülasyonlarını sağlar. Bu bölümde $V_{E, d y n}(z)$ ve $V_{D, d y n}(z)$ hacimlerinin üç boyutlu grafik gösterimleri orijinal ve rafine edilmiș teorilere göre verilmiștir. Şekil 14 ve 15 , üniter narinlik oranı $(H / R=1,00)$, $\mathrm{R}=10 \mathrm{~m}, \gamma=15.000 \mathrm{~N} / \mathrm{m}^{3}, \mu \mathrm{GW}=0,45$ ve $\lambda=0,70$ ile tanımlanan ve dinamik bir girişe maruz bırakılan bir silo için $\mathrm{a}_{\mathrm{eh} 0}=0,30$ ve $\mathrm{a}_{\mathrm{ev} 0}=0$ iki tane tahıl bölümünü göstermektedir.

$\mathrm{V}_{\mathrm{E}, \mathrm{dyn}}(\mathrm{z})$ hacminin Silvestri'nin teorisi ve rafine teorisi için sırasıyla tahılın üst yüzeyine göre bir dışbükey ve içbükey bir şekil aldığı görülmektedir. Eşit dinamik girdi altında, $V_{E \text {,dyn }}(H) / V$ oranı, yani, etkili kütle tarafından kullanılan hacim ile kısmi tane hacmi arasındaki oran, sırasıyla Silvestri'nin teorisine göre \%30 ve rafine teorisine göre \%25 civarındadır. Bu tür değerler, sırasıyla basitleștirilmiş ve Eurocode 8 doğru yöntemle sağlanan \%80 ve \%83 ile karşılaştırıldığında fark edilir bir sonuç verir.
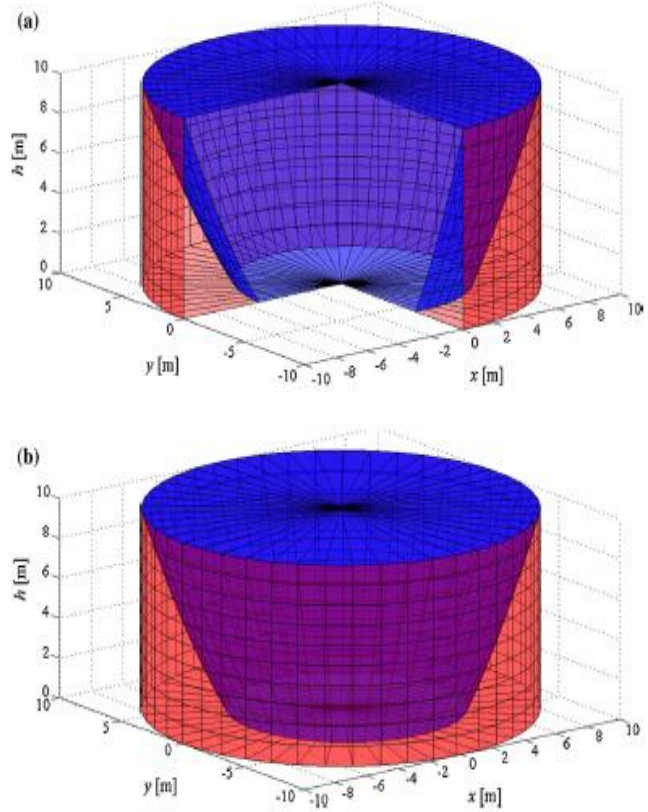

Şekil 14. Silvestri teorisi için düz tabanlı silonun D kısmının (mavi renkte) ve E kısmının (kırmızı renkte) üç boyutlu görünümü: a) kısmi görünüm ve b) genel görünüș (Three-dimensional view of part D (in blue) and part $E$ (in red) of the flat bottom silo for Silvestri theory: a) partial view and b) general view)
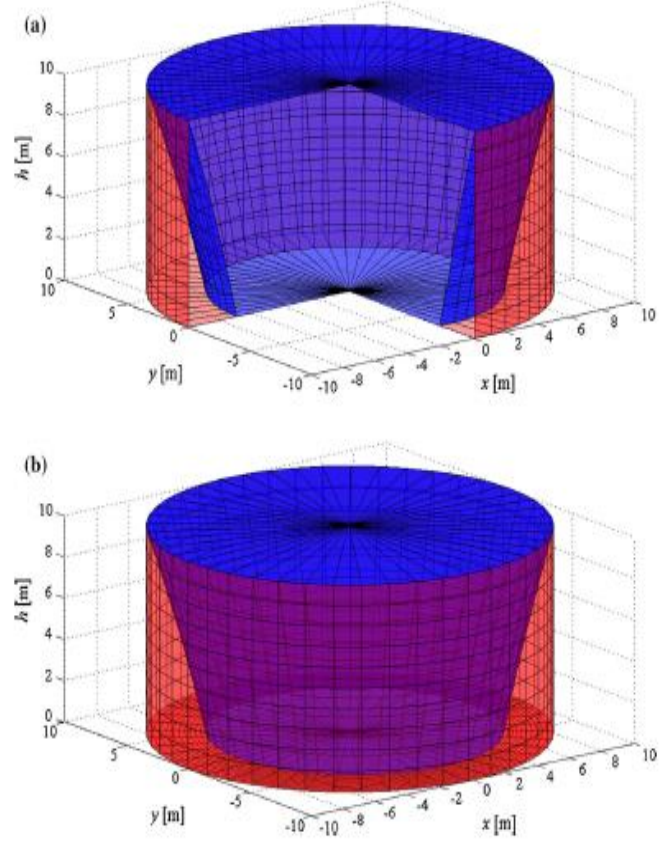

Şekil 15. Rafine teorisi için düz tabanlı silonun D kısmının (mavi renkte) ve E kısmının (kırmızı renkte) üç boyutlu görünümü: a) kısmi görünüm ve b) genel görünüş (Three-dimensional view of part D (in blue) and part $\mathrm{E}$ (in red) of the flat bottom silo for refining theory: a) partial view and b) general view) 


\section{Siloda Taban Kesme Kuvveti ve Eğilme Momenti (Base Shear Force and Bending Moment in Silo)}

Pieraccini ve vd. (2016), etkili kütlenin, radyal aşırı basınçların dikey profilinin, duvar tabanınında kesme gerilmesi ve silo duvarına etki eden devrilme momenti tahmini için bir dizi kod-benzeri formül setini, tahılsilolarının sismik tasarımında kullanılması için önerdiler. Deneysel doğrulama, geniş (squat) silolara atıfta bulunsa bile, literatürde diğer yazarlar tarafından önerilen deneysel bulgular ile karşılaștırılması, gelecekteki deneysel çalışmalar için kabul edilme olasılığını öne sürmüşlerdir(Pieraccini, Palermo, Silvestri, Gasparini, \& Trombetti, 2016). Bu formüller aşağıdaki gibi sıralanabilir.

\section{Analitik Çözüm}

Parametrik çalıșma, siloların sismik tasarımında kullanılan ana miktarların belirlenmesine odaklanır, örneğin: (i) etkili kütle, (ii) maksimum yatay aşırı basınç; (iii) duvarda taban kesme kuvveti ve (iv) Silvestri-Pieraccini formülasyonundan başlayarak duvar tabanı eğilme momenti hesaplanır. Pieraccini dinamik koşullar altında ve Janssen'a göre statik koşullar altında mühendislik açısından bakıldığında, etkili kütle yaklaşık olarak aşağıdaki formülle hesaplanabilir (Pieraccini, Palermo, Stefano, \& Trombetti, 2017; Pieraccini ve vd., 2015);

$$
m_{\text {eff }} \cong 1+\frac{1-e^{\varpi}}{\varpi}
$$

Duvar kesme gerilmesi ile ilgili olarak, etkili kütle ile ilişkili yatay ataleti dengeler, sonuç olarak aşağıdaki formül çlkar.

Duvarda kesme gerilmesi

$$
T=a_{e h 0} \cdot \gamma \cdot\left(\pi R^{2} h_{b}\right) \cdot m_{e f f}
$$

Duvar kaidesinin bükülme momenti $\mathrm{M}=\left(\mathrm{z}=h_{b}\right)$ ile ilgili olarak, duvar kaidesinin $\mathrm{T}$ çarpmasının bir kolun $\mathrm{b}$ ile çarpılması olarak ifade edilebilir:

Eğilme momenti hesabı;

$$
\mathrm{M}=\mathrm{b} . \mathrm{T}
$$

Kod-benzeri formülasyon ile taban kesme kuvveti ve eğilme momenti tahmin edici formüller;

Silo duvarına dinamik koşullar altında etkiyen kuvvetler, silo yüksekliği boyunca dikey ivmenin tekdüze bir dikey profili göz önüne alınarak değerlendirilir. Tahıl ve silo duvarı arasında dinamik şartlar altında yapılan karşılıklı eylemler şöyle sonuçlanır:

\section{Duvarda kesme gerilmesi T (z) sonuçları:}

$$
T(z)=\gamma \int_{0}^{z} a_{e h}(z) \int_{0}^{2 \pi}\left(R . s(z, \vartheta)-\frac{s(z, \vartheta)^{2}}{2}\right) d \vartheta d z(16)
$$

Eğilme momenti M (z) sonuçları:

$$
\begin{array}{r}
M(z)=M_{1}(z)+M_{2}(z) \\
M_{1}(z)=\int_{0}^{z} T_{(z)} \cdot d z \\
M_{2}(z)=\int_{0}^{z} \int_{0}^{2 \pi} T_{v, G W}(z, \vartheta) R^{2} \cos \vartheta d \vartheta d z
\end{array}
$$

Bir siloyu yapısal olarak tasarlayabilmek için bir mühendis, dökme (bulk) katı tarafından meydana gelen yüklere ek olarak rüzgar ve sismik eylemlerden kaynaklanan etkileri de göz önünde bulundurmalıdır. Bu bölümde, tahıl silolarının sismik tasarımı için EN 1998-4 (2006) tarafından sağlanan etkili kütle, radyal aşırı basınçlar ve duvar tabanı kesme kuvveti ve eğilme momenti açısından formüller sunulacaktır.

\section{Taban kesme kuvveti ve taban devrilme momenti için EC8 Tasarım formülleri}

EC8 yönergelerine (B. Standard, 2006), Rotter ve Hull ( 1989)'un sayısal çalışmadaki tahıl silolarının sismik tasarımı (Rotter \& Hull, 1989) ve Pieraccini ve vd. teorik formasyonuna (B. Standard, 2006) 'e göre, tahılın silo duvarında uyguladığı radyal aşırı basınç; 


$$
\Delta p h, s(z)=\alpha(z) \gamma \min \left[\min \left(h_{b} ; \frac{d_{c}}{2}\right) ; 3 x\right]
$$

Tekdüze bir dikey profil göz önüne alındığında, buna karşılık gelen etkin kütle, kesme gerilmesi ve sonuç tarafından verilen eğilme momenti aşağıdaki gibi formülize edilir:

Etkin kütle hesabı;

Taban kesme kuvveti hesabi;

$$
m_{e f f, E C 8}=1-\frac{1}{12 \Delta}
$$

Eğilme momenti hesabi;

$$
T_{E C 8}=\alpha \gamma \cdot m_{e f f, E C 8} \cdot\left(\pi R^{2} h_{b}\right)
$$

$$
M_{E C 8}=\alpha \gamma \cdot \frac{\pi R^{2}}{2}\left(h_{b}{ }^{2}-\frac{R^{2}}{27}\right)
$$

Şekil 16, önceki bölümlerde (Denk. 15) ve EC8 yönergesinde (Denk. 21) önerilen kod benzeri formüllerle düșük genlik artıșına sahip düșük frekanslı taban girișine tabi tutulan silo numunesi için deneysel duvar tabanı eğilme momentini karşılaștırılmaktadır (Pieraccini ve vd., 2016). Yatay ivmenin kritik değeri (a crit $\cong 0,3)$ olana kadar, kod benzeri formülle elde edilen duvar tabanı eğilme momenti, makul bir tahminini sağlarken, deneysel değerlerin \%100'lük sonuçlarını artırdığı gözlemleniyor. Harmonik girdi altında, duvar kaidesinin eğilme momentinin değerleri Eurocode 8 hükümlerine göre elde edilen değerlerin yaklaşık 1/2'sidir.

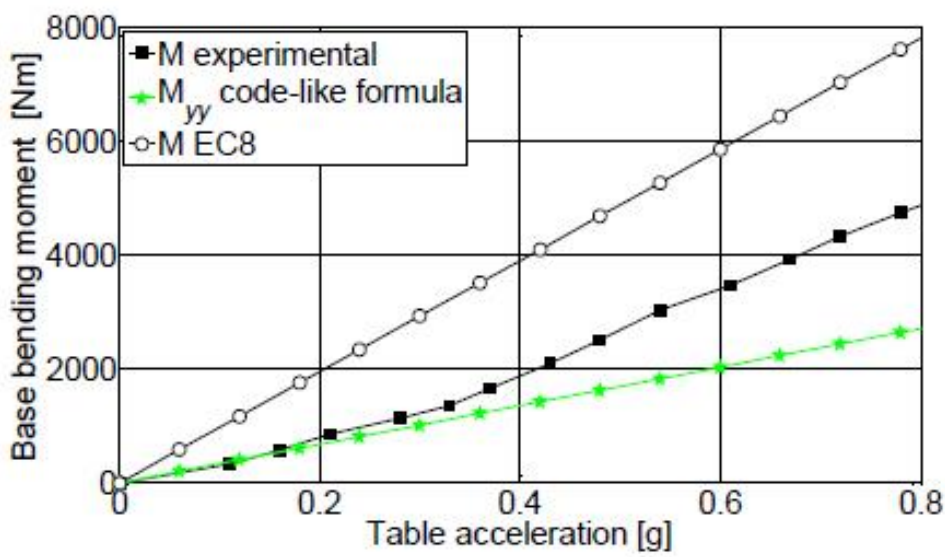

Şekil 16. Eğilme momenti karşılaștırılması (Bending moment comparison)

Pieraccini, ve vd. (2017) mevcut çalışmasında, daha önceki dönemlerde yaptıkları çalışmalarına dayanarak (Silvestri Pieraccini teorisi) tahıl silolarının doğal dönemlerinin değerlendirilmesi için analitik bir formülasyon sunmuşlardır. Yeni formülasyonun öngörüleri deneysel bulgular ile karşılaștırılmıştır. Tahıl silolarının doğal peryotlarının tahmini için analitik bir formülasyon önerilmiștir. Silo, deprem yer hareketi sırasında aktive edilen kısır kütlenin bir kısmına karşılık gelen kütleye artı kütlenin kütlesine eșit olarak uygulanmıș bir kütleye sahip eşdeğer bir kayma-eğilme dirsekli kiriş olarak modellenmiştir. Bunu yaparak, tamamen analitik bir formül elde edilmiştir (Pieraccini ve vd., 2017).

\section{Silo Sismik Tasarımında Yeni Yaklașımlar (New Approaches in Silo Seismic Design)}

Bu çalışma kapsamında, tahıl depolama silolarının sismik analizine katkı sağlamak için, deneysel çalışmalar ve sonlu elemanlar analizinde yeni yaklașım önerileri yer almaktadır. $\mathrm{Bu}$ öneriler doğrultusunda gelecekte gerçekleştirilecek projeler ile tahıl silolarının sismik analizinde önemli mesafeler alınabilir.

\subsection{Tasarım Hataları ve Deneysel Çalışmalar için Öneriler (Suggestions for Design Errors and Experimental Studies)}

Tahıl silolarının yapısal davranışını anlamak için harcanan önemli araștırmalara rağmen, her yıl, diğer yapılardan çok daha fazla sıklıkta, kötü tasarım ve kötü inşaat nedeniyle çok sayıda silo hala hasar görmektedir. Gerçek şu ki, tasarım prosedürlerinin sınırları olduğunu ve bu nedenle silo yapılarının yapısal davranışı bilgisinde önemli gelişmelerin hala gerekli olduğunu göstermektedir. Tahıl-siloların eşleşmiş (tahıl-silo) davranışını daha iyi anlamak için masa üstü ölçekli modellerle çalkalama testleri de dahil olmak üzere son yıllarda bazı deneysel testler yapılmıştır. Deneysel çalışmaların yanı sıra, sonlu elemanlar metodu ile yapılmış birçok çalışma vardır. Fakat bu çalışmalar, silo tasarımcıları ve üreticileri için anlaşılabilir nitelikte içerik sağlayamamaktadır. 
Burada, deneysel modellerin gerçekte kullanılan modelleri tam olarak temsil etmediği ve sonlu elemanlar modelinin tanecikli dökme malzemeyi (bulk material) simule edemedikleri ifade edilebilir. Şekil 17 da Silvestri ve vd. (2016), sarsma tablası testi literatürdeki önemli çalışmalardan biri olmakla birlikte, genelde konik çatı şeklinde imal edilen silo modelini ve davranışlarını yansıtamamaktadır (Silvestri ve vd., 2016). Şekil 18. deki Butenweg ve vd. (2017), yapmıșolduğu sonlu elemanlar modelinde tanecik ile silo arasında contact eleman kullanılsa da, dökme malzemenin silindirik bir kütle olarak modellenmesi, gerçek tane-tane ve tane-silo etkileşimini temsil etmemektedir. Benzer şekilde Livaoğlu ve Durmuş çalışması (2015) ve Mehretehran ve Maleki (2018) çalışması da benzer șekilde yapıldığından, tahıl depolama silolarının sonlu elemanlar modelinin yeni bir anlayışla ela alınmasında olacağını göstermektedir (Livaoglu \& Durmuş, 2016; Mehretehran \& Maleki, 2018).

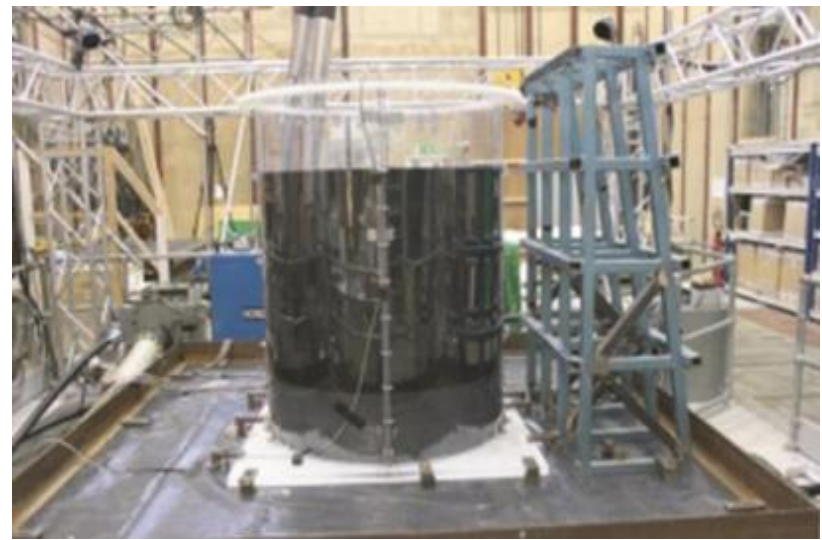

Şekil 17. Silvestri ve vd. Sarsma tablası testi (Silvestri et al. Shaking table test)

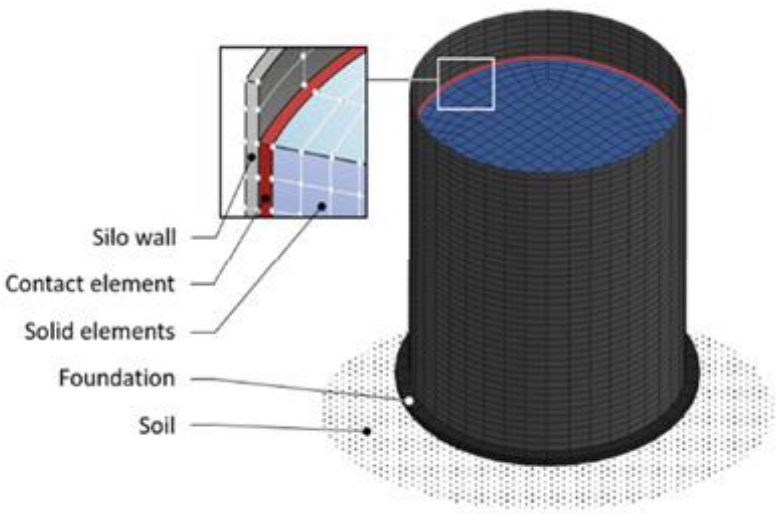

Şekil 18. Butenweg ve vd., sonlu elemanlar modeli (Butenweg ve vd., sonlu elemanlar modeli)

Literatürde daha önce yapılmış deneysel çalışmalarda kullanılan benzer silo modeli üstü açık olarak yapılmıştır, hâlbuki silonun çatı şekli, yatayda ve dikeyde meydana gelebilecek kuvvetlerin dağılımı noktasında önem arz etmekte ve hasar durumlarını büyük oranda değiștirmektedir. Şekil 19'da görüldüğü gibi sismik yükleme altında konik çatı çökmesi meydana gelebilmektedir. Tahıl depolama siloların çatıları genellikle 30 derecelik bir koni şeklinde tasarlanmaktadır, bu model olduğu gibi ölçeklenerek sarsma tablasında kullanılabilir, ayrıca tahılların dinamik hareketlerini gözlemleyebilmek için silo içeresine IP kameralar yerleştirilerek içindeki dökme malzemenin dinamik hareketleri gözlemlenebilir. 


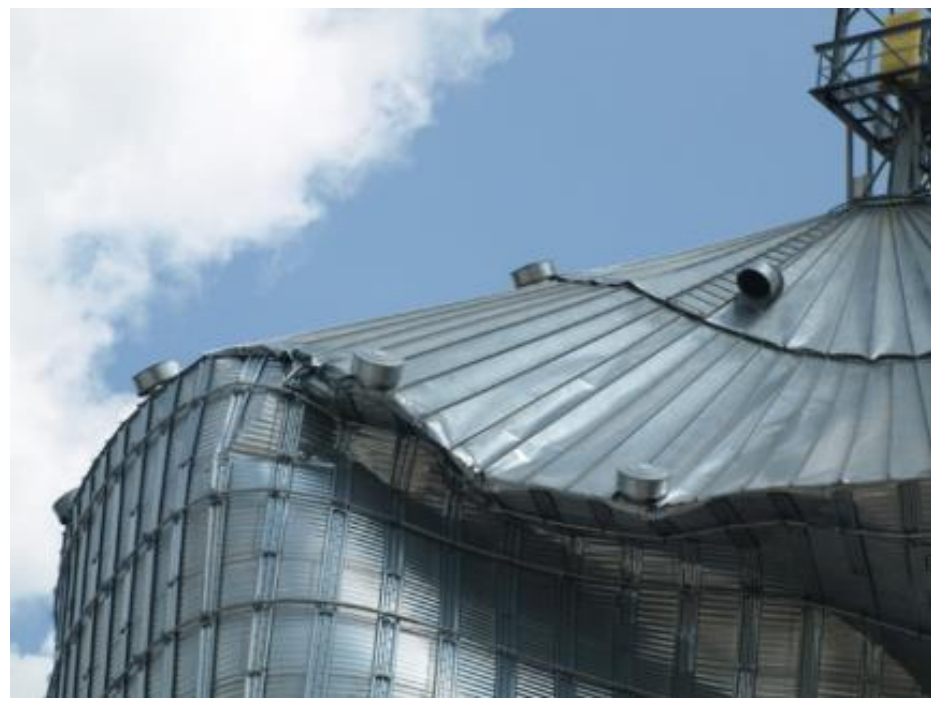

Şekil 19. Silo çatısının çökmesi (Collapse roof of silo)

Dinamik sismik analizi gerçekleştirmek için deprem araştırma laboratuvarları kullanılabilir. Şekil 20. de görüntüsü verilen SANLAB SMotion 3000 markalı sarsma tablası 2.5x2.5 m boyutlarında, altı serbestlik dereceli ve $2000 \mathrm{~kg}$ 'llk yük kapasitesine sahiptir. Üretici firma tarafından sağlanan yük kontrol yazılımı vasıtasıyla sarsma tablasında sinüzodial yük uygulanabileceği gibi El-Centro ve Kocaeli gibi deprem kayıtları da uygulanabilmektedir (Cihaz Kataloğu). Böyle bir sarsma tablası ile üretici firmalar tarafından ölçeklenerek üretilecek, tahıl depolama siloları birçok açıdan, farklı parametrelerle, ayrıntılı analizlerinin yapılması mümkündür.

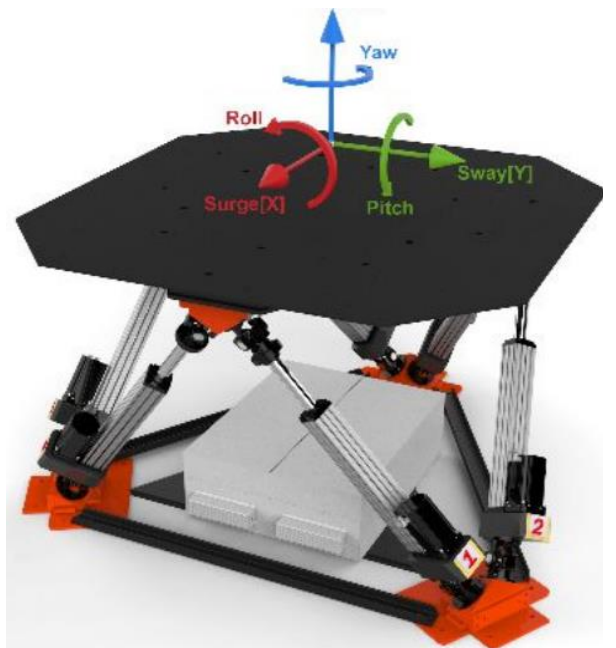

Şekil 20. DOF Sarsma tablası (DOF Shacking table)

\subsection{Sonlu Elemanlar Metodunda Yeni Yaklaşımlar (New Approaches in Finite Element Method)}

Ayrık Eleman Modelleme (DEM-Discrete element method) teknolojisi ile desteklenen EDEM yazılım sayesinde, her türlü tahıl, kömür, mayınlı cevherler, toprak, tablet ve tozlar gibi dökme malzemelerin davranışını hızlı ve doğru bir şekilde simülasyonunu ve analizlerini yapmak mümkündür. EDEM ile yapılan simülasyonlarının temel adımları parçacık üretimi, temas algılama, kuvvet ve momentlerin hesaplanması, hareket denkleminin çözümü, yeni pozisyonların değerlendirilmesi ve yeni etkileşim kuvvetlerinin belirlenmesinde, temas yasalarının kullanılması şeklindedir. Simülasyon sonuçlarının değerlendirilmesini sağlayan her zaman bazı görselleștirme motorları vardır. EDEM simülasyonunun muhtemel hataları, parçacıklar için rijit cisim modelinin kullanılmasından ve parçacıklar arasındaki etkileşimi etkileyen mikromekanik parametrelerin belirlenmesinin zorluklarıdır. Simülasyonlardaki hata olasılıkları nedeniyle, simülasyonlar deneysel sonuçlarla karşılaştırılabilir (simulation, 2019).

Örnek bir parçacık modeli için buğday tanecikleri, sırasıyla $3 \mathrm{~mm}$ veya $2.5 \mathrm{~mm}$ yarıçaplarına sahip üç küre oluşturulabilir. Kürelerin merkezlerinin kenarlar arasındaki uzaklığı 2 mm'dir (Şekil 21.). Bir partikülün kütlesi $0.238 \mathrm{gr}$, atalet momentleri $1.43 \times 10^{-9} \mathrm{kgm}^{2}$ ve $8.015 \times 10^{-10} \mathrm{kgm}^{2}$ dir. Bu çalışma kapsamında bilgisayarda yapılacak analizlerde ilk defa Keppler ve diğerleri(2012) tarafından "Karışık bir akış kurutucuda tane hızı dağılımı” başlıklı 
çalışmasında modellenen ve Oldal ve Safranyik,(2015) boyutları yeniden düzenlenen Şekil 10(a) deki tasarım modeli kullanılmıştır (Keppler, Kocsis, Oldal, Farkas, \& Csatar, 2012; Oldal \& Safranyik, 2015). Bu örnekte, parçacık modeli, sırasıyla $1.5 \mathrm{~mm}$ ve $1.25 \mathrm{~mm}$ yarıçaplara sahip üç küre kümesi şeklindedir. Kürelerin kenarlarındaki kenarlar arasındaki mesafe 1,5 mm'dir.
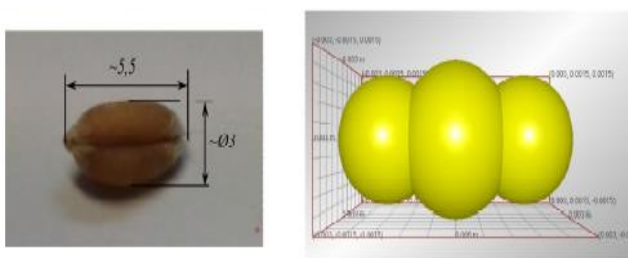

a)

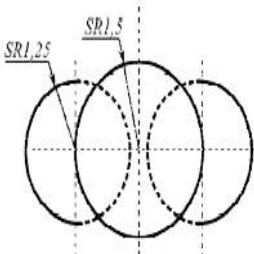

(2)
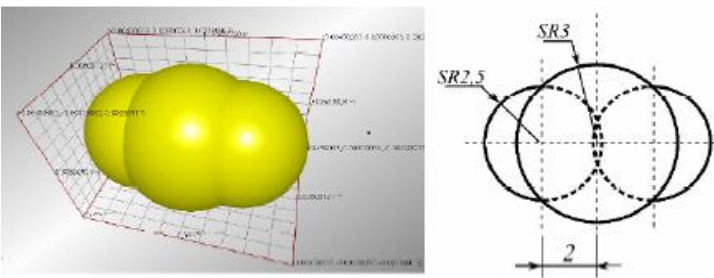

b)

Şekil 21. EDEM yazılım ile buğday tanesi ve geometrisi (Oldal ve Safranyik,(2015) (Wheat grain and geometry with EDEM software (Oldal and Safranyik, (2015))

Şekil 22. deki DEM modeli Horabi ve diğerleri, (2016) tarafından bir sığ model silosunun dibindeki dikey basıncın, radyal dağılımına bir doldurma yönteminin, tohum boyutunun ve tohum en boy oranının etkilerini incelemek için yaptıkları çalışmadan esinlenerek modellenmiştir. Buradan devam ederek düztabanlı silonun sismik yer sarsıntısına verdiği tepkiler belirlemek için kullanılabilir (Horabik, Parafiniuk, \& Molenda, 2016). Deprem ivme değerleri EDEM yazlım içinde verilerek elde edilen kuvvetlerin etkileri ANSYS içerisinde EDEM for ANSYS tool yardımı ile silo üzerindeki etkileri gözlemlenebilir. Önerilen bu yeni analiz yaklaşımına bir ön çalışma niteliğinde, EDEM yazılım kullanılarak ayrık elemanlar olarak buğday tanecikleri modellenmiş ve siloya doldurulmuş (Şekil 22.).

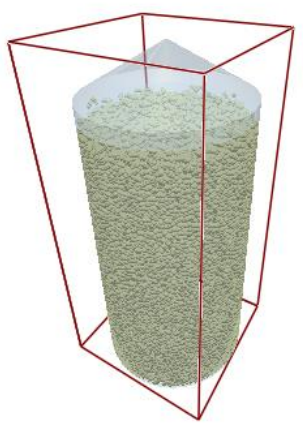

$\sum_{\ln x}^{Z}$

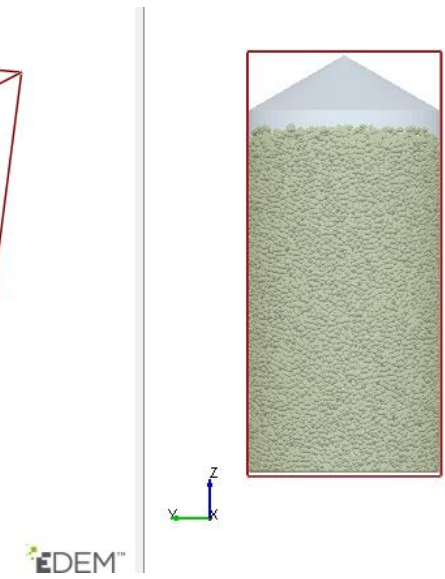

Şekil 22. DEM ile modellenmiş dökme buğday (Bulk wheat modeled with DEM)

ANSYS Sonlu Elemanlar Analizi'nde (Finite Element Analysis- FEA) sıklıkla kullanılan bir yazılımdır, ANSYS için EDEM araç çubuğu sayesinde, kömür gövdeleri, kepçeler, kepçe gövdeleri, kömür, kaya ve benzeri gibi dökme malzemeleri işlemek için tasarlanmıştır. Ağır ekipmanların tasarımında meydana gelen gerilmeler, deformasyonlar ayrıntılı olarak gözlemlemek mümkündür. Burada yola çıkarak Şekil 22, de gösterildiği gibi tahıllar modellenerek, Şekil 23., deki ANSIS için EDEM tool aracılığı ile import ederek, ANSYS içinde modellenen silo içine doldurarak, her türlü sismik analizi yapmak mümkündür.

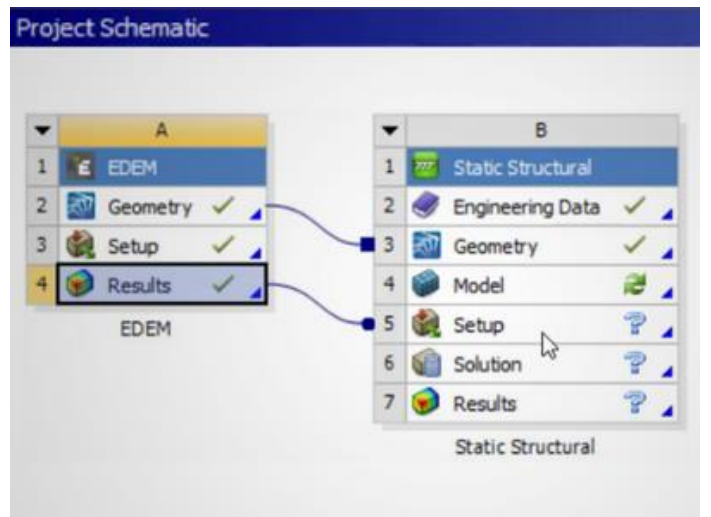

Şekil 23. ANSYS için EDEM tool (EDEM for ANSYS) 


\section{Sonuç (Conclusion)}

Tahıl depolama silolarının sismik tepkisi hala gü çlü belirsizlikler ve araştırma ihtiyacı duyan konular içermektedir. Bu çalıșmada, tahıl benzeri malzeme içeren siloların statik ve sismik tasarımı için teorik çalışmalar ve kod hükümlerine genel bir bakıș sunulmaktadır. Deprem zemin hareketinin düztabanlı tahıl depolama silolarının duvarlarında meydana getirdiği hareketlerle ilgili genel konularda șimdiye kadar yapılmış önemli saha çalışmaları bulunmaktadır. Mevcut tasarım hükümleri de bu çalışmalar ışığında geliştirilmiştir. Dolayısıyla tahıl silolarının tasarım hükümleri de yapısal sismik tasarım ile ilgili konularda eksiklikler içermektedir. Bu konu, ciddi deneysel çalışmalara ve daha gerçekçi sonlu elemanlar analizine ihtiyaç duymaktadır. Bu eksikliklerin giderilebilmesi için, üretici firmaların çalışmaları da dikkate alınarak, deneysel çalışmanın konik silo modeli ile en çok depolanan buğday malzemesi ile gerçekleştirilmesi için altı eksenli sarsma tablası testi tavsiye edilmektedir. Ayrıca sismik analizin çok daha fazla parametre ile sürdürülmesi için sonlu elemanlar metodu ile birlikte ayrık elemanlar metodunun kullanılması bir öneri olarak sunulmuştur. Bu öneriye göre, DEM (discrete element method) yani ayrık elemanlar metodu kullanarak dökme malzeme olarak modellenen, tahıl malzemesinin, ANSIS için EDEM tool aracılığı ile sonlu elemanlar analizine entegre edilerek, daha gerçekçi bir simülasyon ile tanecikler arası boşlukların doğru belirlenmesi ve tane-tane, tane-silo etkileşimini dinamik şartlar altında doğru modellemesi mümkün olacaktır.

\section{Çıkar Çatışması (Conflict of Interest)}

Yazarlar tarafından herhangi bir çıkar çatışması beyan edilmemiştir. No conflict of interest was declared by the authors.

\section{Kaynaklar (References)}

Amundson, L. (1945). Determination of band stresses and lateral wheat pressures for a cylindrical grain bin. Agricultural Engineering, 26, 321-345.

ANSI/ASAE EP433 DEC (R2011)Loads Exerted by Free-Flowing Grain on Bins, USA, EP433 Stat. ( ).

Braun, A., \& Eibl, J. (2009). Pressures under earthquake loading. Silos: fundamental of theory, behavior and design. Taylor \& Francis, London, 518-527.

Butenweg, C., Rosin, J., \& Holler, S. (2017). Analysis of cylindrical granular material silos under seismic excitation. Buildings, $7(3), 61$.

Carson, J., \& Craig, D. (2015). Silo design codes: Their limits and inconsistencies. Procedia engineering, 102, 647-656.

Çelik, A. İ., Köse, M. M., Akgül, T., \& Apay, A. C. (2019). Effects of The Shell Thickness On The Directional Deformation And Buckling On The Cylindrical Steel Water Tanks Under The Kobe Earthquake Loading. Sakarya Üniversitesi Fen Bilimleri Enstitüsü Dergisi, 23(2), 269-281.

Demir, F., \& Saltan, M. (2017). Deprem Etkisi Altında Demiryolu Üstyapısı Davranışının İncelenmesi. Mühendislik Bilimleri ve Tasarım Dergisi, 5, 615-620 doi:10.21923/jesd.283161

Dogangun, A., Karaca, Z., Durmus, A., \& Sezen, H. (2009). Cause of damage and failures in silo structures. Journal of Performance of Constructed Facilities, 23(2), 65-71.

Hirshfeld, D., \& Rapaport, D. (2001). Granular flow from a silo: discrete-particle simulations in three dimensions. The European Physical Journal E, 4(2), 193-199.

Horabik, J., Parafiniuk, P., \& Molenda, M. (2016). Experiments and discrete element method simulations of distribution of static load of grain bedding at bottom of shallow model silo. Biosystems Engineering, 149, 60-71.

Jamieson, J. A. (1903). Grain pressures in deep bins. CSCE Trans. CSCE Trans, 17:554-607(607), 554-607

Janssen, H. (1895). Versuche Uber Getreidedruck in Silozellen Vol. 39. Zeitschrift. Verein Deutcher Ingenieure, Dusseldorf. Germany.

Kanyilmaz, A., \& Castiglioni, C. A. (2017). Reducing the seismic vulnerability of existing elevated silos by means of base isolation devices. Engineering Structures, 143, 477-497.

Keppler, I., Kocsis, L., Oldal, I., Farkas, I., \& Csatar, A. (2012). Grain velocity distribution in a mixed flow dryer. Advanced Powder Technology, 23(6), 824-832.

Koenen, M. (1896). Berechnung des Seiten und Bodendrucks in Silozellen. Centralblatt der Bauverwaltung, 16, 446-449.

Landry, J. W., Grest, G. S., Silbert, L. E., \& Plimpton, S. J. (2003). Confined granular packings: structure, stress, and forces. Physical Review E, 67(4), 041303.

Li, H. (1994). Analysis of steel silo structures on discrete supports.

Livaoglu, R., \& Durmuş, A. (2016). A simplified approximation for seismic analysis of silo-bulk material system. Bulletin of Earthquake Engineering, 14(3), 863-887.

Malhotra, P. (2000). Practical nonlinear seismic analysis of tanks. Earthquake Spectra, 16(2), 473-492.

Mehretehran, A. M., \& Maleki, S. (2018). 3D buckling assessment of cylindrical steel silos of uniform thickness under seismic action. Thin-Walled Structures, 131, 654-667.

Oldal, I., \& Safranyik, F. (2015). Extension of silo discharge model based on discrete element method. Journal of Mechanical Science and Technology, 29(9), 3789-3796.

Ovarlez, G., Fond, C., \& Clément, E. (2003). Overshoot effect in the Janssen granular column: a crucial test for granular mechanics. Physical Review E, 67(6), 060302 
Pieraccini, L., Palermo, M., Silvestri, S., Gasparini, G., \& Trombetti, T. (2016). Seismic horizontal forces exerted by granular material on flat bottom silos: experimental and analytical results.

Pieraccini, L., Palermo, M., Stefano, S., \& Trombetti, T. (2017). On the Fundamental Periods of Vibration of Flat-Bottom GroundSupported Circular Silos containing Gran-like Material. Procedia engineering, 199, 248-253.

Pieraccini, L., Silvestri, S., \& Trombetti, T. (2015). Refinements to the Silvestri's theory for the evaluation of the seismic actions in flat-bottom silos containing grain-like material. Bulletin of Earthquake Engineering, 13(11), 3493-3525.

Pozzati, P., \& Ceccoli, C. (1972). Teoria e tecnica delle strutture (Vol. 2): Utet.

Rankine, W. M. (1857). On the stability of loose earth. Philos Trans R Soc Lond 147,9-27.(147).

Rotter, J. (2001). Guide for the economic design of circular metal silos. Spon. Press. In: Taylor \& Francis Group, London, New York.

Rotter, J., Holst, J., Ooi, J., \& Sanad, A. (1998). Silo pressure predictions using discrete-element and finite-element analyses. Philosophical Transactions of the Royal Society of London. Series A: Mathematical, Physical and Engineering Sciences, 356(1747), 2685-2712.

Rotter, J., \& Hull, T. (1989). Wall loads in squat steel silos during earthquakes. Engineering Structures, 11(3), 139-147.

Schwab, C. V., Ross, I. J., White, G. M., \& Colliver, D. G. (1994). Wheat loads and vertical pressure distribution in a full-scale bin part I-filling. Transactions of the ASAE, 37(5), 1613-1619.

Silvestri, S., Gasparini, G., Trombetti, T., \& Foti, D. (2012). On the evaluation of the horizontal forces produced by grain-like material inside silos during earthquakes. Bulletin of Earthquake Engineering, 10(5), 1535-1560.

Silvestri, S., Ivorra, S., Chiacchio, L. D., Trombetti, T., Foti, D., Gasparini, G., .. . Taylor, C. (2016). Shaking-table tests of flat-bottom circular silos containing grain-like material. Earthquake Engineering \& Structural Dynamics, 45(1), 69-89.

Simulation, E. (2019). EDEM simulation. Retrieved from https://www.edemsimulation.com/software/

Standard, A. (1996). Loads on Bulk Solids Containers, 1996. Standards Association of Australia, 23.

Standard, B. (2006). Eurocode 1: Actions on structures.

Tatko, R., \& Kobielak, S. (2008). Horizontal bulk material pressure in silo subjected to impulsive load. Shock and Vibration, 15(5), 543-550.

Trahair, N., Abel, A., Ansourian, P., Irvine, H., \& Rotter, J. (1983). Structural design of steel bins for bulk solids. Australian Institute of Steel Construction, Sydney, Australia, 30.

Vanel, L., Claudin, P., Bouchaud, J.-P., Cates, M., Clément, E., \& Wittmer, J. (2000). Stresses in silos: comparison between theoretical models and new experiments. Physical review letters, 84(7), 1439.

Veletsos, A. S., \& Younan, A. H. (1998). Dynamics of solid-containing tanks. II: Flexible tanks. Journal of Structural Engineering, 124(1), 62-70.

Yaylacı, M., \& Terzi, C. (2018). Temas Problemlerinde Sonlu Elemanlar Yönteminin Doğruluğunun İncelenmesi. Mühendislik Bilimleri ve Tasarım Dergisi, 6 (3), 511-519 . doi:0.21923/jesd.407121 